\title{
Late Palaeozoic strike-slip tectonics versus oroclinal bending at the SW outskirts of Baltica: case of the Variscan belt's eastern end in Poland
}

\author{
Stanislaw Mazur ${ }^{1}$ (D) Paweł Aleksandrowski ${ }^{2,3} \cdot$ Łukasz Gągała $^{4} \cdot$ Piotr Krzywiec $^{5} \cdot$ Jerzy Żaba $^{6} \cdot$ Krzysztof Gaidzik $^{6}$. \\ Rafał Sikora ${ }^{3}$
}

Received: 4 June 2019 / Accepted: 22 December 2019 / Published online: 9 January 2020

(c) The Author(s) 2020

\begin{abstract}
Geophysical and geological data from the eastern sector of the Central European Variscan belt are presented and reviewed in the regional tectonic context. Matched filtering of isostatic gravity, guided by results of spectral analysis, along with other derivatives of gravity and magnetic fields reveal a dominant WNW-ESE-trending pre-Permian structural grain in the external zones of the Variscan belt in Poland. This trend is confirmed by regional distribution of dips in Carboniferous and Devonian strata that were penetrated by boreholes beneath Permian-Mesozoic sediments. Based on these data, two alternative concepts explaining the connection of the Variscan belt and its NE foreland, those of strike-slip tectonics versus oroclinal bending, are discussed. The WNW-ESE structural trend in the Variscan foreland is parallel to a set of major strike-slip fault zones in the area, including those of Upper Elbe, Intra-Sudetic, Odra, Dolsk and Kraków-Lubliniec. These faults are considered to convey a significant dextral displacement between Laurussia and Gondwana. The revised position of the Variscan deformation front shows a similar, uninterrupted, generally WNW-ESE trend, up to the SE border of Poland, which indicates an initial continuation of the Variscan belt into the area of the present-day Western Carpathians. The geometry of the Variscan deformation front along with the pattern of the Variscan structural grain are inconsistent with the idea of an oroclinal loop affecting the external, non-metamorphic Variscan belt. However, the data presented do not entirely rule out an oroclinal loop within the Variscan internides. The still possible options are (1) a semi-oroclinal model postulating $\sim 90^{\circ}$ bending of the Variscan tectonostratigraphic zones into parallelism with the WNW-ESE strike-slip faults or (2) an orocline limited only to the belt linking the Wolsztyn High and Moravo-Silesian non- to weakly-metamorphic fold-and-thrust belt. Regardless of the kinematic model preferred, our data indicate that structural evolution of the Polish Variscides was concluded with the end-Carboniferous NNE-SSW shortening that resulted in the present-day extent of the Variscan deformation front.
\end{abstract}

Keywords Central Europe · Carboniferous · Variscan foreland · Variscan deformation front · Rhenohercynian · MoravoSilesian · Sudetes · Bohemian Massif · Gravity and magnetic data

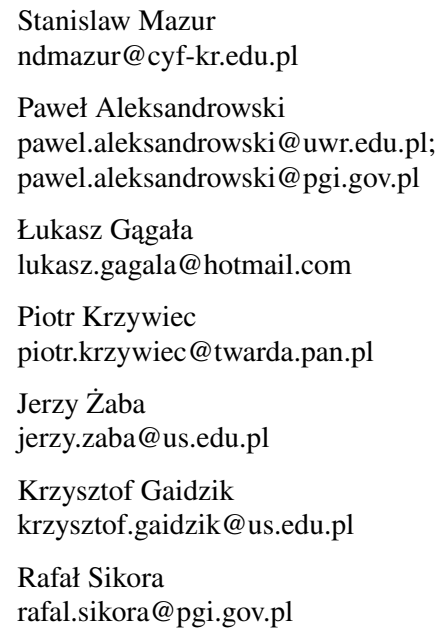
in Kraków, Senacka 1, 31-002 Kraków, Poland

2 Institute of Geological Sciences, University of Wroclaw, Cybulskiego 32, 50-205 Wrocław, Poland

3 Polish Geological Institute-National Research Institute, Rakowiecka 4, 00-975 Warsaw, Poland

4 Hellenic Petroleum, Maroussi, Greece

5 Institute of Geological Sciences PAS, Research Centre in Warsaw, Twarda 51/55, 00-818 Warsaw, Poland

6 Institute of Earth Sciences, University of Silesia, Będzińska 60, 41-200 Sosnowiec, Poland 


\section{Introduction}

The European Variscan belt sharply changes its trend in easternmost Germany and western Poland, with respect to that prevailing in Germany and eastern to central France (Fig. 1). The ENE- to NE-striking structures are replaced there by those of the 'Sudetic' ESE- to SE-trending ones (Fig. 1), which are especially clear in the well exposed mountainous areas of the Variscan internides of the West and Central Sudetes at the NE margin of the Bohemian Massif and, therefore, has been reflected on all regionalscale geological maps since the $19^{\text {th }}$ century. The structures of still another, NNE-SSW strike, take the lead, however, in the East Sudetes and along the south-eastern margin of the Bohemian Massif (Fig. 1). In this way, at the north-eastern end of the latter, the Variscan belt makes nearly a U-turn, encircling the Bohemian Massif from the north. It is, thus, no surprise that these radical changes of Variscan structural trends have been explained for almost a century by assuming a $180^{\circ}$ oroclinal loop, in which the Rhenohercynian and Saxothuringian tectonostratigraphic zones inarm the Moldanubian/Tepla-Barrandian core (e.g. Kossmat 1927; Lorenz 1976; Ellenberger and Tamain 1980; Lorenz and Nicholls 1984; Engel et al. 1983; Franke 1989a, b; Pożaryski and Karnkowski 1992; Pożaryski et al. 1992; Tait et al. 1997; Narkiewicz 2007). According to this classical view, the outermost tectonostratigraphic zone of the Variscan belt, the Rhenohercynian Zone of Germany, continues eastward in the deep substratum of the PermianMesozoic German-Polish Basin and reappears at the surface along the eastern rim of the Bohemian Massif as the Moravo-Silesian Zone in eastern Czechia and southern Poland (including the eastern part of the East Sudetes). In the somewhat modified version of the oroclinal concept, Franke and Żelaźniewicz $(2000,2002)$ correlated the area

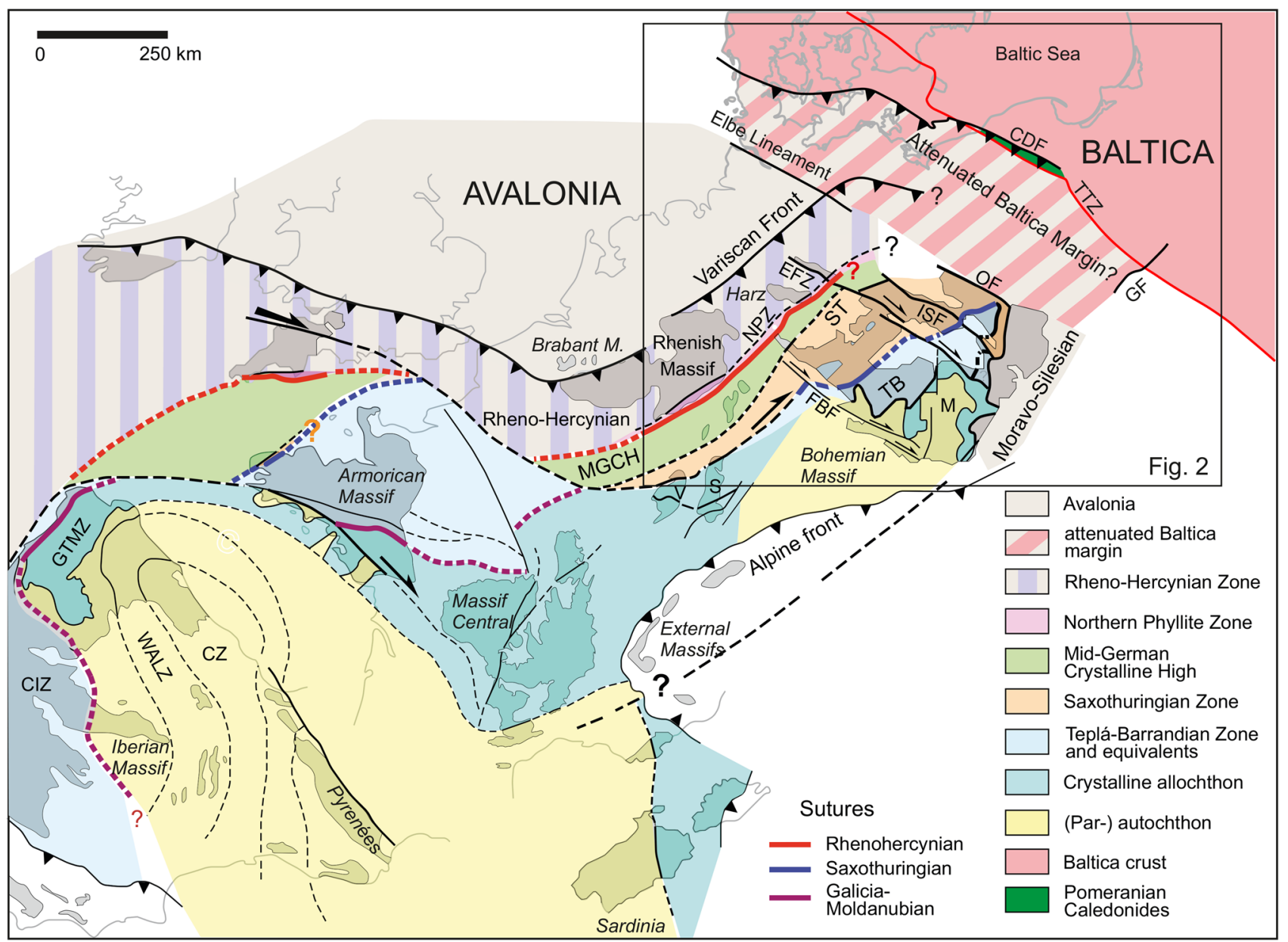

Fig. 1 European Variscan belt with palinspastic restoration of Iberia prior to the opening of the Bay of Biscay. Modified from various sources including Martínez Catalán (2011) and Franke (2014). CZ Spanish Central Zone, CIZ Central Iberian Zone, EFZ Elbe
Fault Zone, FBF Franconian-Bavarian Fault, GTMZ Galicia-Tras os Montes Zone, ISF Intra-Sudetic Fault Zone, $M$ Moldanubian Zone, NPZ Northern Phyllite Zone, $O F$ Odra Fault Zone, $S$ Schwarzwald, $S T$ Saxothuringian Zone, TB Teplá-Barrandian Zone, $V$ Vosges 
SW of the Odra Fault with the Mid-German Crystalline High and the Wolsztyn High with the Northern Phyllite Zone, but have not openly suggested a continuation of the main, anchizonal part of the Rhenohercynian belt along the Baltica margin.

Since the late 1970s, an alternative view has gained an increasing attention that postulates a dextral transpressional regime during the final accretion of the Variscan terranes (Dewey and Burke 1973; Arthaud and Matte 1977; Badham 1982; Behr et al. 1984; Weber 1986; Matte 1991). The transpressive character of the Variscan shortening, accommodated by prominent NW-SE dextral faults, was suggested by gravimetric and magnetic maps (Edel and Weber 1995) and a joint structural and paleomagnetic study (Edel et al. 2018). This transpressional tectonic context is believed to have resulted from sublatitudinal, dextral displacements between the Gondwana and Baltica-Avalonia margins of Laurussia during Carboniferous to early Permian times (Arthaud and Matte 1977; Lewandowski 2003; Eckelmann et al. 2014). Near the Carboniferous-Permian boundary, Gondwana decoupled from the newly formed European Variscan belt and proceeded westward, toward the southern edge of the Laurentian segment of Laurussia, owing to the development of the Appalachian subduction system (Ziegler 1989). Concomitantly with the peak of the Alleghanian orogeny during early Permian time (c. 290 Ma; e.g. Hatcher 2002; Bartholomew and Whitaker 2010), the European Variscan belt experienced reactivation of its major tectonic zones along a set of dextral strike-slip faults (Arthaud and Matte 1977; Badham 1982; Behr et al. 1984).

Arthaud and Matte (1977) proposed that a series of NW-SE-trending major strike-slip faults interrupting the continuity of the Variscan-Appalachian orogenic belt along a c. $6000 \mathrm{~km}$ long and more than $1000 \mathrm{~km}$ wide brittle megashear zone. In consequence, dismembered fragments of several Variscan tectonostratigraphic zones can be found in the Sudetes Mountains (SW Poland) and, potentially, underneath the German-Polish Basin, being dextrally displaced parallel to the Teisseyre-Tornquist Zone along the SW margin of the East European Craton (Fig. 2; Aleksandrowski 1990, 1995; Aleksandrowski et al. 1997; Aleksandrowski and Mazur 2002). According to this model, the Rhenohercynian and Moravo-Silesian Zones are not linked, but the latter represents an intra-Variscan suture zone along an active margin of the Brunovistulian Terrane (e.g. Matte et al. 1990; Aleksandrowski 1995). The existence of important WNW-ESE dextral dislocations was also acknowledged by Franke and Żelaźniewicz $(2000,2002)$, who included these features in their model of the 'Bohemian Arc' corresponding to a dissected Variscan orocline.

Recent years have brought important advancements in the recognition of the eastern Variscides. Firstly, a Variscan thinskinned fold-and-thrust belt has been seismically recognised in SE Poland (Krzywiec et al. 2017a, b). Tectonic imbrication of Ediacaran to Carboniferous sediments overlying the SW slope of the East European Craton demonstrate that the Variscan belt was effectively terminated against a rigid buttress of the Precambrian crystalline basement, which occurred there at shallow depths. Secondly, an increasing body of evidence supplements the firmly established knowledge on a widespread occurrence of Variscan basement fragments involved in the Central and Inner Carpathian orogenic belts (e.g. Jeřábek et al. 2008; Králiková et al. 2016; Gawęda et al. 2017), well beyond the traditionally accepted extent of the Variscan orocline of SW Poland. All these new discoveries, combined with the hitherto known facts, call for re-evaluation of the orocline- and strike-slip models.

The objective of the present paper is twofold. First, we investigate directions and continuity of structural trends in the external zones of the Variscan orogen in Poland and map a foreland extent of Variscan deformations using gravimetric-magnetic and borehole data. Second, we highlight structural similarities and differences between the sectors of the Variscan externides located on either side of the presumed oroclinal loop. These permit us testing the orocline- vs strike-slip concepts and develop an overall kinematic model for the NE Variscides.

\section{Geophysical and structural data processing}

Gravity and magnetic data used in this study come from the Central Geological Database (Central Geological Database 2019) operated by the Polish Geological Institute. Since the magnetic field attenuates faster than the gravity field with increasing distance from a source, magnetic anomalies are more accurate at revealing shallow features located within the upper and middle crust, such as e.g., the top of magnetic basement, whereas the gravity field has a better potential to represent deeper crustal structures (Blakely 1996). Magnetic susceptibility of sedimentary rocks is one order of magnitude weaker than that of crystalline rocks, and, thus, sedimentary cover is practically transparent for the magnetic field, despite of possible local occurrences of intra-sedimentary volcanic rocks.

\section{Gravity data}

The gravity database contains measurements derived from more than 800,000 ground stations uniformly covering the territory of Poland. The gravity data were enhanced by a complete Bouguer correction using a digital terrain model and slab density of $2.67 \mathrm{~g} / \mathrm{cm}^{3}$. The gravity datum used was the international gravimetric standard IGSN71 and theoretical gravity was based on the GRS80 reference ellipsoid. 


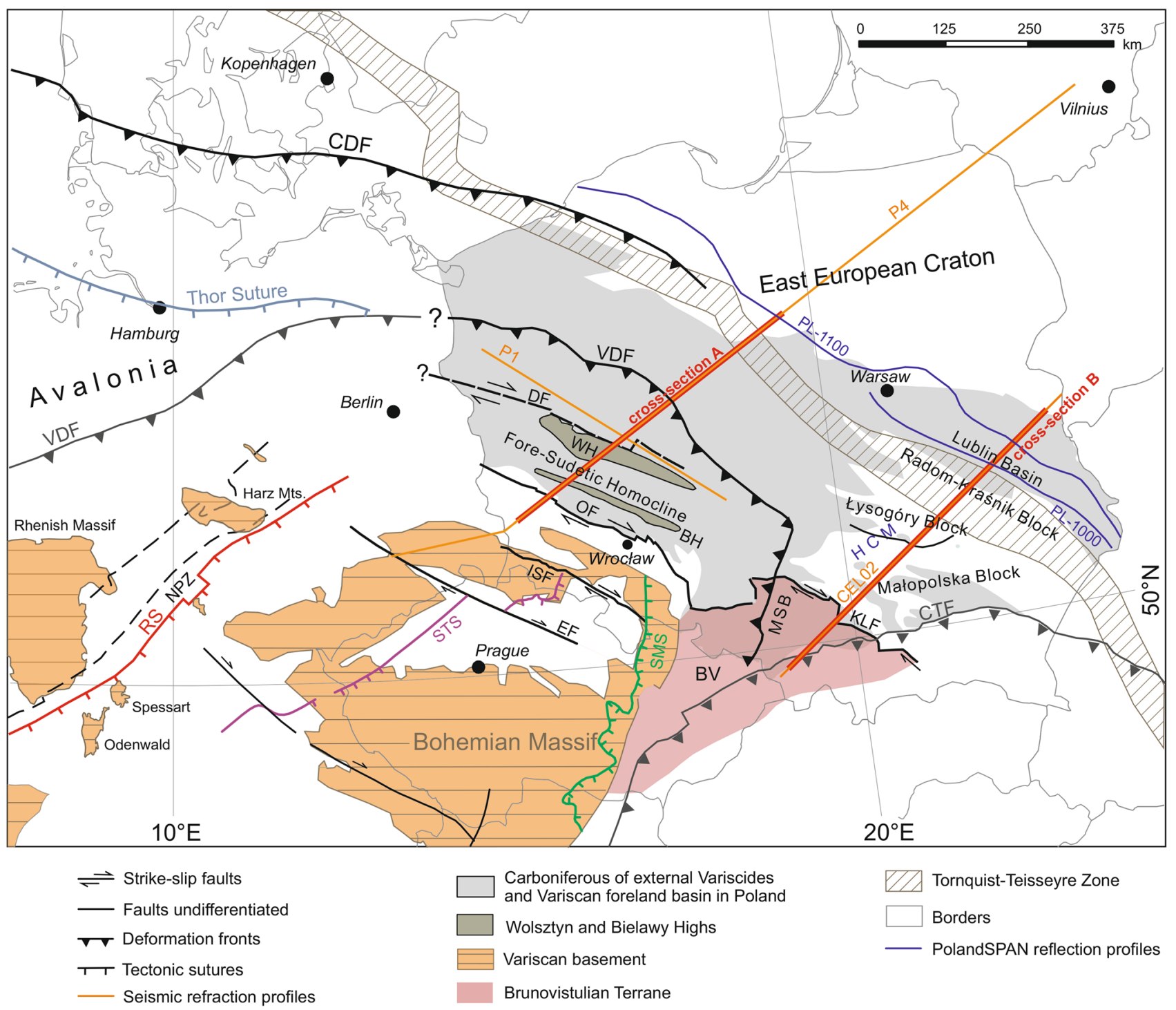

Fig. 2 Simplified tectonic map of Central Europe showing the tectonic sutures and strike-slip faults discussed in the text. Base map modified from several sources including Franke et al. (1995), Pharaoh (1999) and Banka et al. (2002). Orientation of the Variscan deformation front in Poland after Jubitz et al. (1986). $B H$ Bielawy High, $B V$ Brunovistulian terrane, $C D F$ Caledonian deformation front,

The configuration of Moho can have a large influence on the gravity anomalies because the density contrast between the lower crust and upper mantle is $\mathrm{c.} 0.35 \mathrm{~g} / \mathrm{cm}^{3}$ in the study area (e.g. Mikołajczak et al. 2019). If the crust is in isostatic equilibrium (Airy-type), then the topography should be compensated by corresponding changes in the depth to the Moho, and this relationship can be used, along with the seismic refraction-based Moho grid (Majdański 2012), to model the gravitational effect of the Moho. The depth of the compensating root at $33 \mathrm{~km}$ was assumed in the calculation. This isostatic gravitational effect was
$C T F$ Carpathian thrust front, $D F$ Dolsk Fault, $E F$ Upper Elbe Fault, $H C M$ Holy Cross Mountains, ISF Intra-Sudetic Fault, KLF KrakówLubliniec fault, $M S B$ Moravo-Silesian belt, $N P Z$ Northern Phyllite Zone, $O F$ Odra Fault, RS- Rhenohercynian Suture, SMS Staré Město (Moravian) Suture, STS Saxothuringian Suture, VDF Variscan Deformation Front, $W H$ Wolsztyn High

then subtracted from the Bouguer anomaly to produce an isostatic residual anomaly (Fig. 3) which should highlight the remaining lateral density contrasts that exist within the crust (e.g. Simpson et al. 1986; Nabighian et al. 2005). The isostatic residual anomaly map (Fig. 3) enhances the gravity anomalies related to features at crustal level by removing long-wavelength anomalies related to Moho undulations or upper mantle variability. The isostatic residual gravity data were gridded at a $2000 \mathrm{~m}$ interval, using a minimum curvature algorithm. 
Fig. 3 Potential field maps of Poland with main structural elements overlaid: isostatic residual gravity map (a) and reduced-to-pole (RTP) magnetic anomaly map (b). A coordinate system used in this and following figures is Poland 1992 that is based on the ETRS89 datum, GRS80 ellipsoid and the Transverse Mercator projection with $19^{\circ} \mathrm{E}$ as a central meridian. White dashed polygon shows the range of data used in spectral analysis. $D F$ Dolsk Fault, $O F$ Odra Fault, ISF IntraSudetic Fault, KLF KrakówLubliniec Fault, MSB MoravoSilesian fold-and-thrust belt, SMS Staré Město Suture, STS Saxothuringian Suture, VDF (A) Variscan Deformation Front after Jubitz et al. (1986), VDF (B) Variscan Deformation Front after Pożaryski et al. (1992), $V D F$ Variscan Deformation Front (this study)
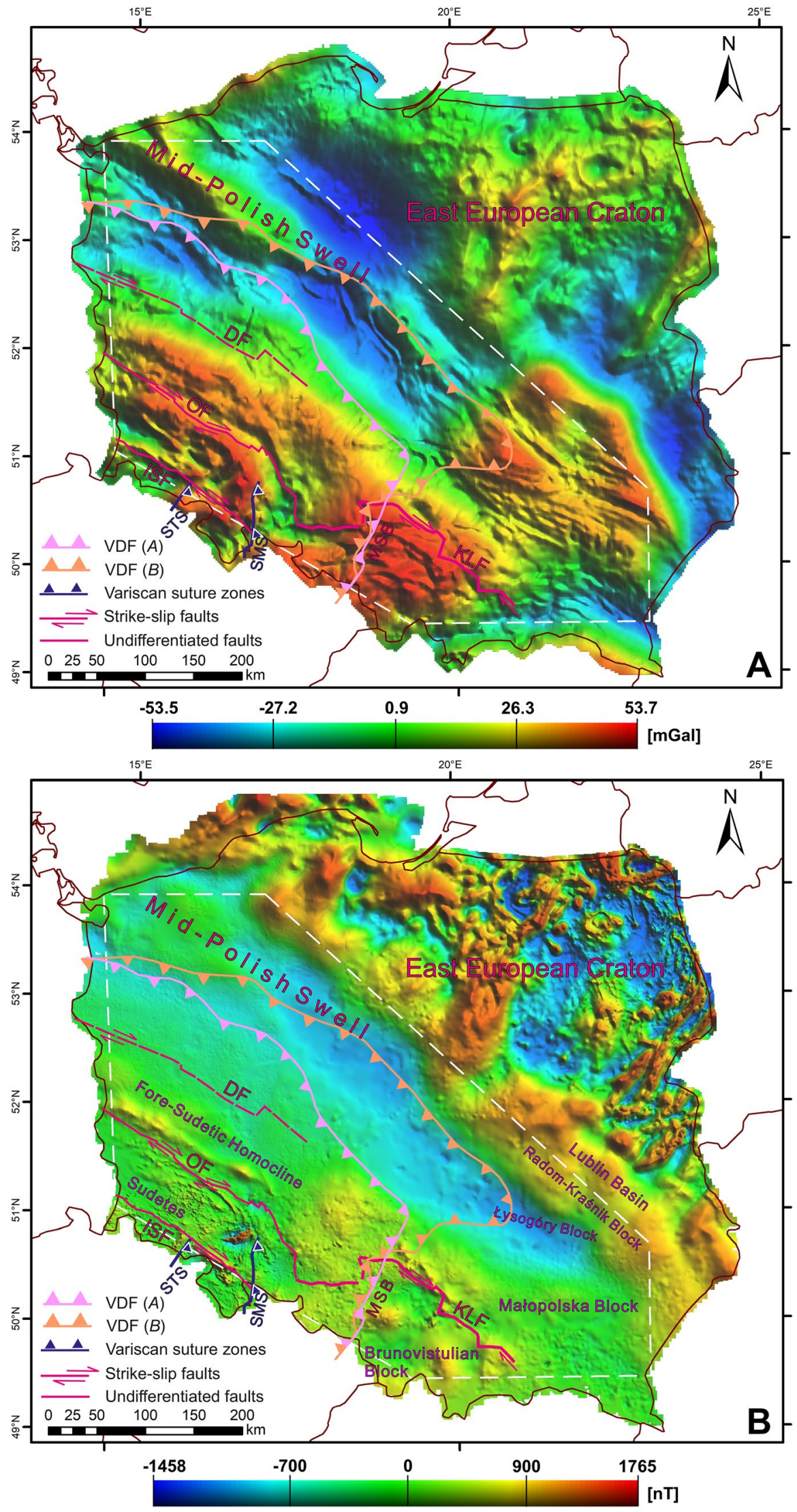


\section{Magnetic data}

The magnetic data base included nearly 800,000 measurements of the Total Magnetic Intensity (Central Geological Database 2019) that were compiled from a number of ground and airborne surveys. These data were gridded at a $500 \mathrm{~m}$ interval using a minimum curvature algorithm and upward continued to $500 \mathrm{~m}$ mean terrain clearance. The magnetic anomaly data were enhanced using the reductionto-pole (RTP) transform because of the vector nature of magnetization and variations in the inclination and declination of Earth's magnetic field with latitude (Fig. 3). The RTP transform attempts to simplify the magnetic field by rotating the magnetic vector to be vertical, thereby centring magnetic anomalies above their causative bodies (MacLeod et al. 1993).

\section{Matched filtering}

In general, the anomalies with long wavelengths are supposed to be produced by deep sources within the lower crust or upper mantle. The exception are laterally extensive, shallow bodies with gentle dips, as they can also generate long wavelength anomalies. In contrast, the short wavelength anomalies are related to shallow sources in the upper crust. On the whole, there is no straightforward relationship between the depth to a source and the wavelength of gravity and magnetic anomalies. A rule of thumb is that the depth to a causative body corresponds to $1 / 3$ to $1 / 4$ of the anomaly wavelength (Fairhead 2016).

Spectral analysis (Spector and Grant 1970; Syberg 1972) has been applied to magnetic and gravity anomalies to estimate the contributions from sources located at different depths and, thus, constrain the deep structure of the crust. This approach can bring valuable information on location and geometry of major crustal boundaries as well as orientation of dominant structural grain, especially in the absence of good quality seismic sections. The separation of the gravity and magnetic signal into components generated at different depths can be achieved using the matched filtering technique (Syberg 1972).

Matched filtering is a pseudo-depth slicing technique which allows an anomaly separation based on anomalies' different wavelengths. The method is based on the analysis of the Fourier power spectrum of gravity or magnetic data. The power spectrum is separated into several sections of roughly uniform slope (Fig. 4), each of them corresponding to an equivalent layer of specific depth (Spector and Grant 1970). These depths are assumed to represent the most important density and susceptibility contrasts within the crust and confine fairly coherent crustal bodies. The depth range between equivalent layers provides a guidance for designing a bandpass filter, which amplifies signals produced by sources within a certain level of the crust and attenuates anomalies generated at different levels. Consequently, anomaly maps of band-pass filter derivatives emphasize the lateral density and susceptibility contrasts within the corresponding depth range of the crust.

The Fourier power spectra of gravity or magnetic data (Fig. 4) were generated using GETgrid software package from Getech Group plc. (Getech 2019). GETgrid uses a system, where the Nyquist wavenumber is set to be $\pi$. The Nyquist wavenumber (or strictly, the equivalent 1D Nyquist wavenumber) is the highest wavenumber that can be isotropically represented in the grid and has wavelength of twice the grid cell size. Thus, the wavenumber on the GETgrid horizontal axis has the value of $2 \times$ cell_size $\times \pi / \lambda$, where $\lambda$ represents the wavelength measured in the same units as the grid (Fig. 4). Depth in the ground units of the grid can be picked from gravity or magnetic data using the Spector and Grant (1970) approach based on formula: depth $=1 / 4 \pi \times \Delta \ln P / \Delta k$, where $k=1 / \lambda$.

\section{Structural data}

Structural data comprise more than 400 boreholes, published refraction seismic profiles P4 and CEL02 (Grad et al. 2003; Malinowski et al. 2005) and subsurface maps of the basePermian-Mesozoic subcrop (Pożaryski and Dembowski 1983; Buła and Habryn 2011).

The borehole data come from the Central Geological Database (2019), where most of the boreholes have formation tops and structural information from cored intervals: dip angles, core-scale structures and core descriptions. The cores are, however, unoriented. Few recently drilled deep boreholes with classified tops, but available termination depth (TD) stratigraphy were used in the most underconstrained areas.

The structural data were used in a twofold manner. First, integrated datasets were employed to construct two crustalscale cross-sections. Shallow subsurface was constrained by boreholes projected within a $10 \mathrm{~km}$ swath. Given a large number of boreholes along some segments of the cross-sections, a preference was given to those that penetrate pre-Permian stratigraphic or/and structural contacts and those containing dip data in the pre-Permian section. Seismic refraction profiles P4 and CEL02 provided key constraints on deep geometries (Grad et al. 2003; Malinowski et al. 2005). Published results of seismic interpretation were used as proxies to structural styles (Antonowicz et al. 2003; Krzywiec et al. 2017a; Tomaszczyk and Jarosiński 2017; Krzywiec et al. 2018; Kufrasa et al. 2019). Second, maximum dip readings from Carboniferous and/or Devonian intervals in each borehole have been contoured to produce a country-wide map of maximum dips in the external Variscan belt. The vast number (403) of boreholes used for contouring helped to overcome the inherent 
A

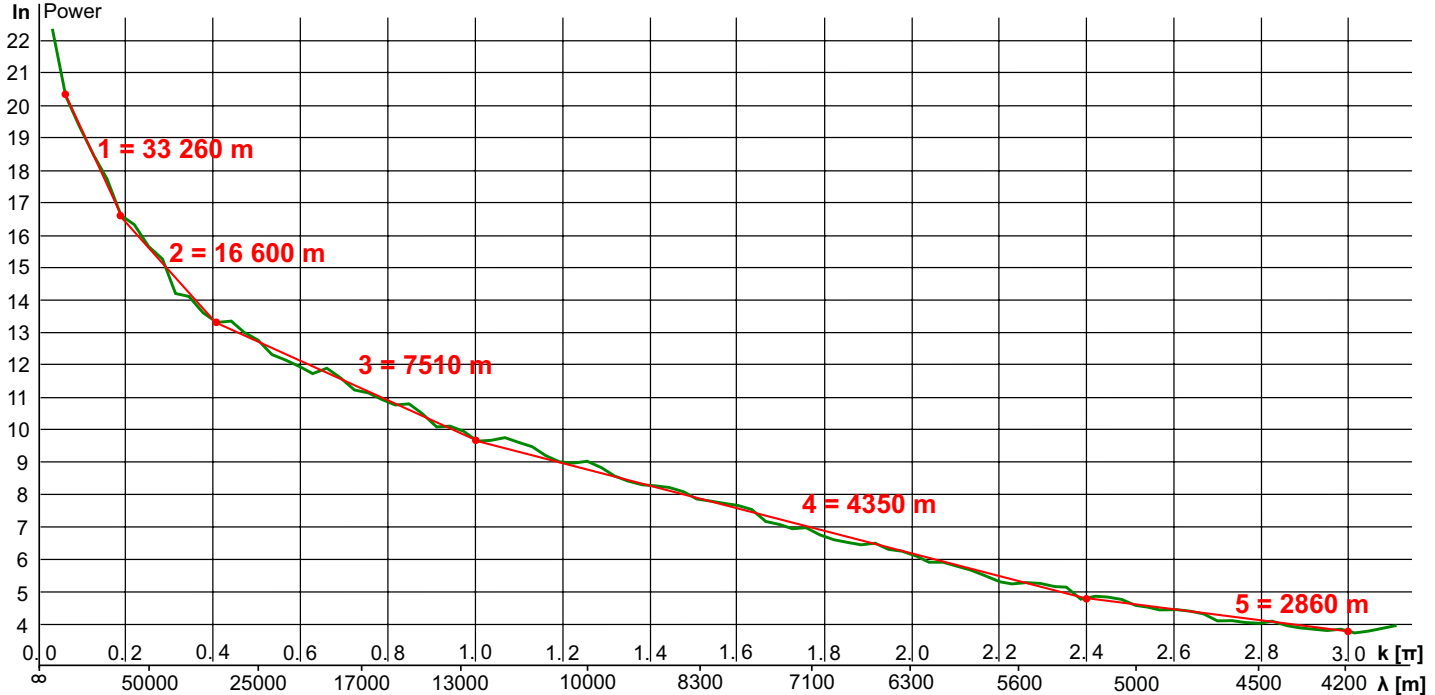

B In Power

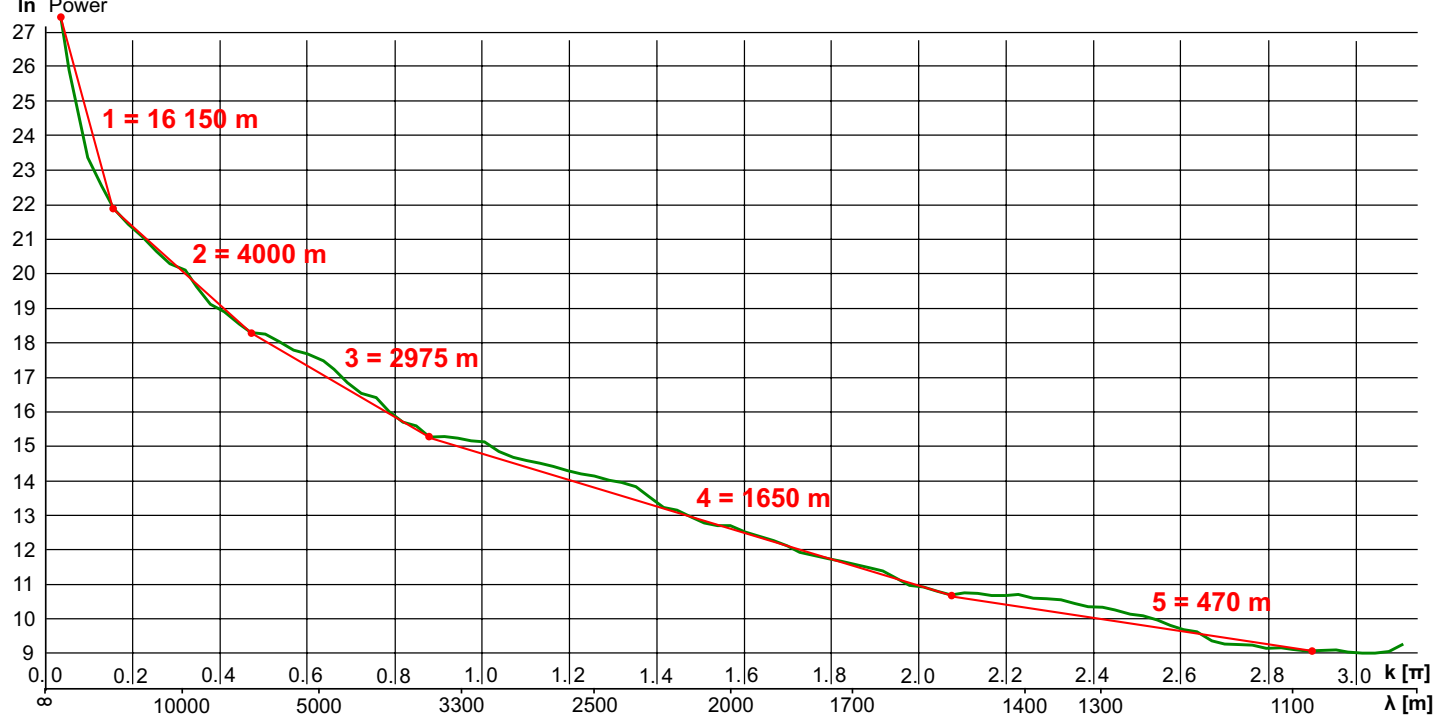

Fig. 4 Power spectra and depth slicing results for isostatic residual anomalies (a) and reduced-to-pole (RTP) magnetic anomalies (b). The extent of data used is shown in Fig. 7. The wavenumber $\mathrm{k}$ on the horizontal axis has the value $2 \times$ cell size $\times \pi / \lambda$, where $\lambda$ represents wavelength in ground units (metres). For the gravity grid (a), $k=\pi$ at $\lambda=4000$ since the grid cell size is $2000 \mathrm{~m}$. For the magnetic grid (b), $k=\pi$ at $\lambda=1000$ since the cell size is $500 \mathrm{~m}$. Depths are calculated based on formula: $h=1 / 4 \pi \times \Delta \ln P / \Delta k$, where $k=1 / \lambda$ bias related to: various lengths of sampled intervals, various number and density of dip readings, presence of non-tectonic folds (e.g. slumped intervals), post-Variscan deformation, and various quality of core descriptions. This method allowed outlining the little deformed Variscan foreland and approximating a position of the Variscan deformation front.

\section{Interpretation of gravity and magnetic anomaly maps}

Our study is based on gravity and magnetic data since the Variscan foreland in Poland is entirely concealed beneath 
Permian-Mesozoic and Cenozoic sediments. We applied spectral analysis to constrain the bandpass filtering of gravity data and emphasize the trend of structural grain recorded in the pre-Permian rocks.

In general, spectral analysis is sensitive to the size of a window that is used for the calculation. Since the focus of this paper is on regional problems, data from the entire Palaeozoic Platform in Poland were employed in the analysis. The scope of data is shown in Fig. 3 as a white, dashed polygon, the NE boundary of which roughly coincides with the Teisseyre-Tornquist Zone. This way, the area analysed covers the entire extent of the eastern Variscides in Poland, regardless a position of the Variscan deformation front previously proposed (Fig. 3). The radial power spectrum of the isostatic residual gravity data can be split into five sections, corresponding to discrete equivalent layers at depths of $33,260 \mathrm{~m}, 16,600 \mathrm{~m}, 7500 \mathrm{~m}, 4350 \mathrm{~m}$ and $2860 \mathrm{~m}$ (Fig. 4a). The first one corresponds to the average position of the Moho discontinuity (Majdański 2012; Grad and Polkowski 2016). The depth of $16,600 \mathrm{~m}$ can be interpreted as a depth to the top of middle crust beneath the Palaeozoic Platform in western Poland (outside the Bohemian Massif) based on estimates from compilations of seismic refraction data (Guterch and Grad 2006) or representative seismic refraction profiles (Grad et al. 2003, 2008). The middle crystalline crust is characterised by seismic $\mathrm{P}$-wave velocities in the range of 6.2-6.6 km/s (Guterch and Grad 2006) and in most locations probably represents the Precambrian crystalline basement. The top of the deformed lower Palaeozoic succession can be assumed at the average depth of $7500 \mathrm{~m}$ in the area of the Palaeozoic Platform beyond the Bohemian Massif. The mean depth to the top of folded and thrust Carboniferous strata (Variscan unconformity) corresponds to $4350 \mathrm{~m}$. However, this is not the case in the part of the ForeSudetic Homocline adjacent to the Sudetes and within the Brunovistulian Block (Fig. 3). Therefore, the latter depth slice of $2860 \mathrm{~m}$, less important for the goal of this study, may correspond to the top of Carboniferous in these areas. Alternatively, it may represent the top of the Permian evaporitic succession in the area of the Palaeozoic Platform.

The radial power spectrum of the RTP magnetic data can be split into sections, corresponding to 5 discrete equivalent layers at depths of $16,150 \mathrm{~m}, 4000 \mathrm{~m}, 2975 \mathrm{~m}, 1650 \mathrm{~m}$ and $470 \mathrm{~m}$ (Fig. 4b). The deepest one is equivalent to the crystalline middle crust, whose nature is also revealed by the power spectrum of gravity data, the top of which represents an important density and susceptibility contrast. The depth of $4000 \mathrm{~m}$ may correspond to the top of the deformed Carboniferous succession or, more likely, the top of the directly overlying, lowermost Permian volcanic rocks (e.g. Geißler et al. 2008). The next two equivalent layers (2975 and $1650 \mathrm{~m}$ ) probably represent the top of basement in the areas of thin sedimentary cover extending over the SW part of the Fore-Sudetic Homocline and the Brunovistulian Block. The shallowest equivalent layer corresponds to the Variscan crystalline basement exposed in the Sudetes.

According to the present state of the art, the external Variscides in Poland represent a fold-and-thrust belt (e.g. Mazur et al. 2006a, 2010) in accord with the seismic profiles from SE Poland (Lublin Variscides; Krzywiec et al. 2017a, b) and surface data from the Moravo-Silesian foldand-thrust belt (Rajlich 1990b; Bábek et al. 2006; Fig. 3). Therefore, beyond the Bohemian Massif, Variscan deformation is mostly localised within sedimentary or low-grade rocks of the pre-Permian age. According to the power spectrum analysis, such rocks are comprised in a depth interval between 16,500 and $4300 \mathrm{~m}$. Using a common assumption that the depth of a causative body is between $1 / 3$ and $1 / 4$ of the anomaly wavelength (e.g. Fairhead 2016), the cutoff frequencies for the band-pass filter were adjusted to the depth of the selected equivalent layers using power spectrum analysis as guidance. Band-pass filtering (13-50 km) of the isostatic residual gravity anomalies suppressed gravity anomalies coming from the sources shallower than $\sim 4.3 \mathrm{~km}$ and deeper than $\sim 16.5 \mathrm{~km}$ (Fig. 5).

The area of the Palaeozoic Platform in Poland is dominated by two superimposed structural trends emphasized by band-pass filtering (Fig. 5). One is oriented WNW-ESE and corresponds to a dominant Variscan structural grain (Fig. 6). This is confirmed by the similar orientation of structural trend in the area of the Sudetes. Superimposition on the similarly oriented Caledonian grain in the far Variscan foreland is not excluded though difficult to prove. The other structural grain runs NW-SE, parallel to the MidPolish Swell (Figs. 5, 6). The origin of this structural trend is related to the Late Cretaceous inversion of the PermianMesozoic Polish Basin that inverted its depocentre, known as the Mid-Polish Trough, into the Mid-Polish Swell and reversed many normal faults (e.g. Dadlez et al. 1995). The WNW-ESE oriented Variscan grain extends mostly undisturbed across the Variscan foreland from western Poland to the Holy Cross Mts. and the Lublin Basin (Figs. 5, 6, 7). The exception makes the Odra Fault and gravity anomalies adjacent from the north and south. They gradually bend SEward c. $40^{\circ}$ toward the NNW-SSE orientation (Figs. 5, 7). Consequently, the Odra and Kraków-Lubliniec Faults are presently not aligned in one continuous feature although they both separate two contrasting domains: (1) the area to the south with strong, short-wavelength gravity anomalies representing relatively shallow basement, and (2) the area of lower amplitude and longer wavelength anomalies related to deeper basement in the north (Figs. 5, 7).

Although the location of the major Variscan structural elements (the Intra-Sudetic, Odra, Dolsk and KrakówLubliniec Faults, Holy Cross Fault, front of the MoravoSilesian belt, Saxothuringian and Staré Město Sutures) were 
Fig. 5 Butterworth bandpass filter of the isostatic residual gravity with cut-off wavelengths of 50 and $13 \mathrm{~km}$. Filter order: 2. Match-filtering highlights anomalies arising from sources located between the top of pre-Permian rocks $(\sim 4300 \mathrm{~m})$ and the top of crystalline middle crust $(\sim 16,500 \mathrm{~m})$. Pale yellow dashed lines emphasize WNWESE oriented Variscan structural grain. $D F$ Dolsk Fault, $O F$ Odra Fault, ISF Intra-Sudetic Fault, KLF Kraków-Lubliniec Fault, MSB Moravo-Silesian fold-and-thrust belt, SMS Staré Město Suture, STS Saxothuringian Suture, $V D F$ Variscan Deformation Front

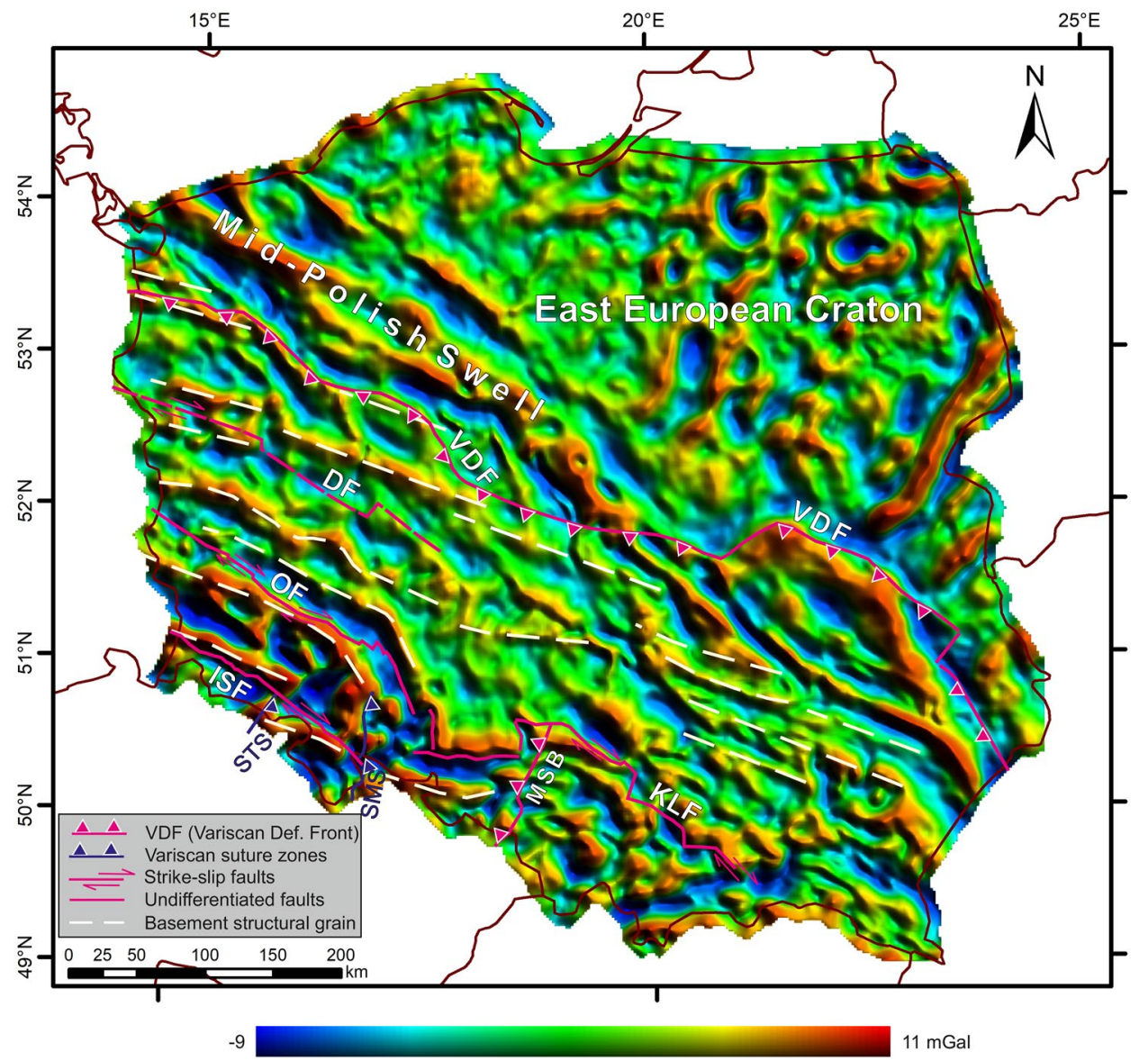

not interpreted from the potential field data but compiled from regional maps available in the literature (Pożaryski and Dembowski 1983; Dadlez et al. 2000; Buła and Habryn 2011, Buła et al. 2015) they usually have a good expression in the anomaly patterns (Figs. 3, 5, 7). Instead, the band-pass filter and total horizontal derivatives were used to interpret the orientation of the Variscan structural grain and, along with the data on maximum dips in Devonian-Carboniferous strata (see below), the position of the Variscan deformation front (Figs. 5, 7).

The position of the Variscan deformation front in the east (Lublin Basin) is constrained by good quality seismic data (Krzywiec et al. 2017a, b; Tomaszczyk and Jarosiński 2017). The interpreted position of the front farther NW relies on the band-pass derivative and distribution of structural dips. For reference, two most popular previous interpretations of the Variscan front in Poland (Jubitz et al. 1986; Pożaryski et al. 1992) are plotted on Fig. 3. They both make an oroclinal loop cross-cutting the WNW-ESE oriented structural grain along their N-S oriented sections (Figs. 5, 6, 7). This is important to note that the Variscan front in Poland consists of two independent segments. Besides the main stretch that is oriented WNW-ESE, approximately parallel to the Odra and Kraków-Lubliniec Faults, there is also a N-S oriented section in Upper Silesia, corresponding to the frontal thrust (Orłowa Thrust) of the Moravo-Silesian fold-and-thrust belt (Figs. 5, 7). A continuation of this deformation zone beyond the Kraków-Lubliniec Fault is unclear.

Two early Carboniferous Variscan suture zones, the Saxothuringian and Staré Město Sutures, are, to some extent, imaged by potential field data in the Sudetes (Figs. 3, 5, 7). They are oriented NNE-SSW, roughly parallel to the suture zones in the German Variscides (e.g. Franke et al. 2017). Both the sutures are cut-off by the Intra-Sudetic Fault (though in different manner due to a late reversal of the sense of motion on the latter fault-see Aleksandrowski 1995; Aleksandrowski et al. 1997) and do not continue northward into the Variscan foreland.

\section{Cross-sections through the external variscides}

Two regional cross-sections ' $A$ ' and ' $B$ ' intersect the Variscan belt on either side of the traditionally presumed oroclinal bend (Figs. 2, 8). Both cross-sections are tied to the East European Craton (EEC) that represents the ultimate foreland of Variscan deformations. Cross-section A passes 

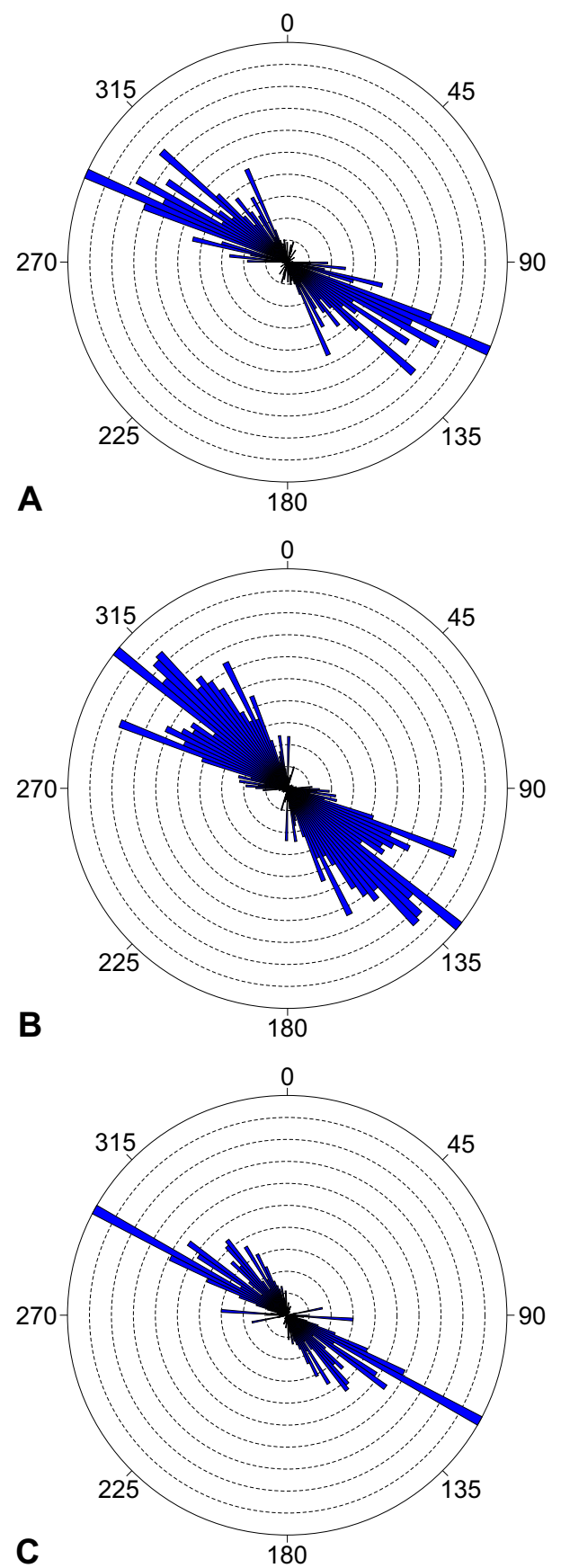

Fig. 6 Circular histogram plots (rose diagrams) displaying direction and frequency of lineaments in geophysical anomaly maps: a bandpass filtered isostatic residual gravity (Fig. 5), b total horizontal derivative of isostatic gravity (Fig. 7a), and $\mathbf{c}$ total horizontal derivative of RTP magnetic anomaly (Fig. 7b). A narrow frequency range of $5^{\circ}$ was applied (72 intervals) to differentiate between the WNWESE Variscan structural grain and NW-SE trend of the end Cretaceous inversion structures. Histograms are weighted on length with reference to the most populous interval. Data are collected from the area covered by spectral analysis (white dashed polygon in Fig. 3). Note weak expression of the NE-SW trend among magnetic lineaments (c) through the Carboniferous fold-and-thrust belt subcropping at the base-Permian in $\mathrm{W}$ Poland and terminates in the metamorphic hinterland. Cross-section B crosses the main structural units of SE Poland: Lublin Basin, RadomKraśnik High, Łysogóry and Małopolska Blocks and Brunovistulian Terrane. It terminates in the Alpine allochthonous units of the Outer Carpathians that conceal a southern continuation of Variscan structures. Radial power sections for gravimetric and magnetic datasets are indicated next to the cross-sections.

\section{Cross-section A}

Palaeozoic substrate along cross-section A is buried under a thick Permian-Mesozoic succession of the German-Polish Basin. The top-Palaeozoic is situated $5 \mathrm{~km}$ b.s.l. in the depocentre and rises SW and NE towards the Sudetes and EEC, respectively. The top-basement is constrained in the extreme NE of the cross-section by a seismic tie from the PolandSPANTM PL1-1100 line (Krzywiec et al. 2014). Elsewhere, an interpretative top-basement velocity interface from the P4 profile is used (Grad et al. 2003; Fig. 8). The refraction top-basement steeply descends SW of the Karnkowo IG-1 borehole (Fig. 8) that, together with the rise of the Moho, results in abrupt thinning of the EEC crystalline crust from $35-38$ to $16-18 \mathrm{~km}$. The thin crust is considered a Baltica's rifted passive margin (Grad et al. 2003; Mazur et al. 2015a; Mikołajczak et al. 2019). The SW limit of the thinned EEC crust is not constrained as the main velocity intervals pinchout progressively at the transition into the low-velocity Variscan crust.

Carboniferous flysch has been drilled region-wide below the base-Permian unconformity. Most of the boreholes stopped after drilling short intervals (100-200 m) of the Carboniferous strata, but a few penetrated more than $1000 \mathrm{~m}$. While the short Carboniferous intervals drilled do not permit construction of a structural cross-section, distribution of dip angles provides proxy to the structural style. Moderate to steep $\left(30^{\circ}-80^{\circ}\right)$ dips predominate across the Carboniferous subcrop over a distance of $\sim 160 \mathrm{~km}$. No clear steepening/ shallowing trend is observed. We interpret the predominance of moderate to steep dips as an expression of thin-skinned folding and/or imbricate stacking of the Carboniferous series. Alternative solution would be a thick-skinned inversion, but this structural style normally results in broad low-to medium, dip domains separated by narrow steep domains, opposite to the frequency of dip angles in the boreholes. The borehole data leave a broad margin of uncertainty for a position of the Variscan deformation front. There exists a big gap in borehole coverage across the depocentre of the German-Polish Basin, between boreholes Września IG-1 and Byczyna 1 (Fig. 8). Both boreholes drilled steeply dipping Carboniferous strata that may suggest that the Variscan 
Fig. 7 Gravity and magnetic derivative maps of Poland with main structural elements overlaid: a total horizontal derivative of isostatic gravity, and $\mathbf{b}$ total horizontal derivative of RTP magnetic anomaly. $D F$ Dolsk Fault, $O F$ Odra Fault, $I S F$ Intra-Sudetic Fault, $K L F$ Kraków-Lubliniec Fault, $M S B$ Moravo-Silesian fold-and-thrust belt, SMS Staré Město Suture, STS Saxothuringian Suture, $V D F$ Variscan Deformation Front

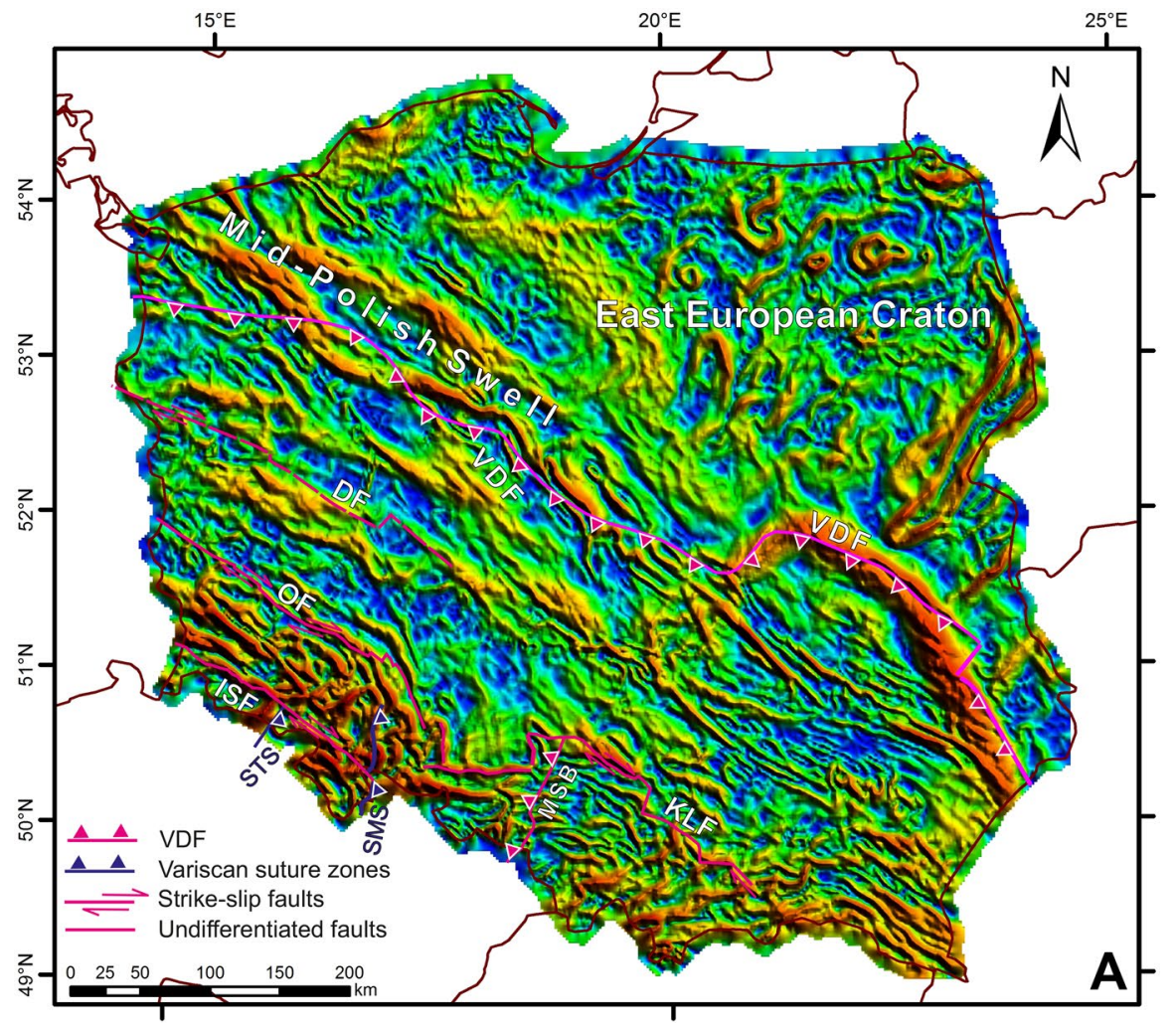

$\begin{array}{llllllllll}0.00004 & 0.00023 & 0.00035 & 0.00045 & 0.00055 & 0.00067 & 0.00082 & 0.00103 & 0.00155\end{array}$

$[\mathrm{mGal} / \mathrm{m}]$

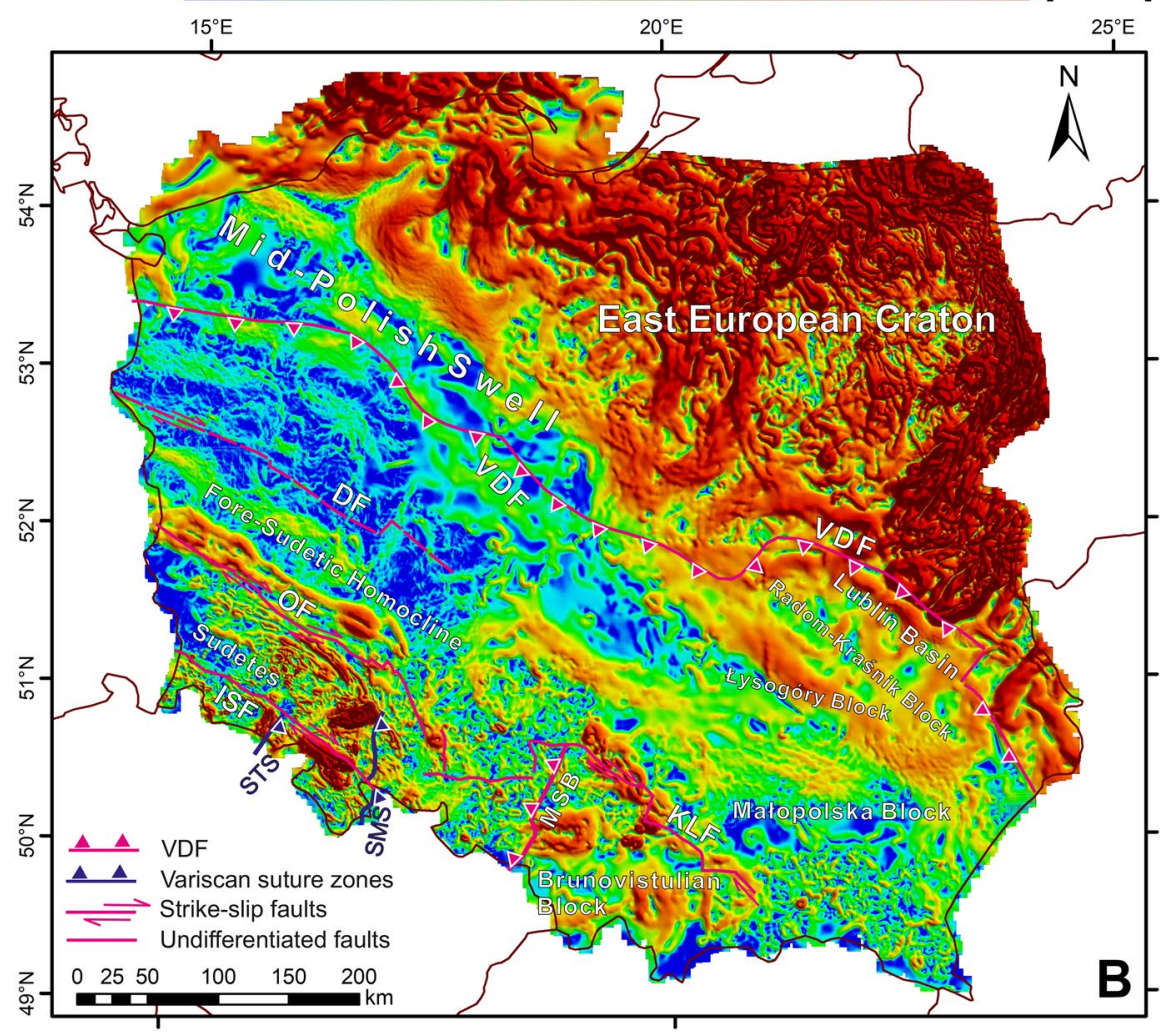

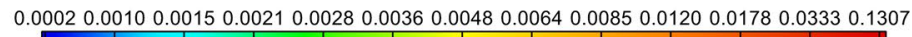
$[\mathrm{nT} / \mathrm{m}]$ 


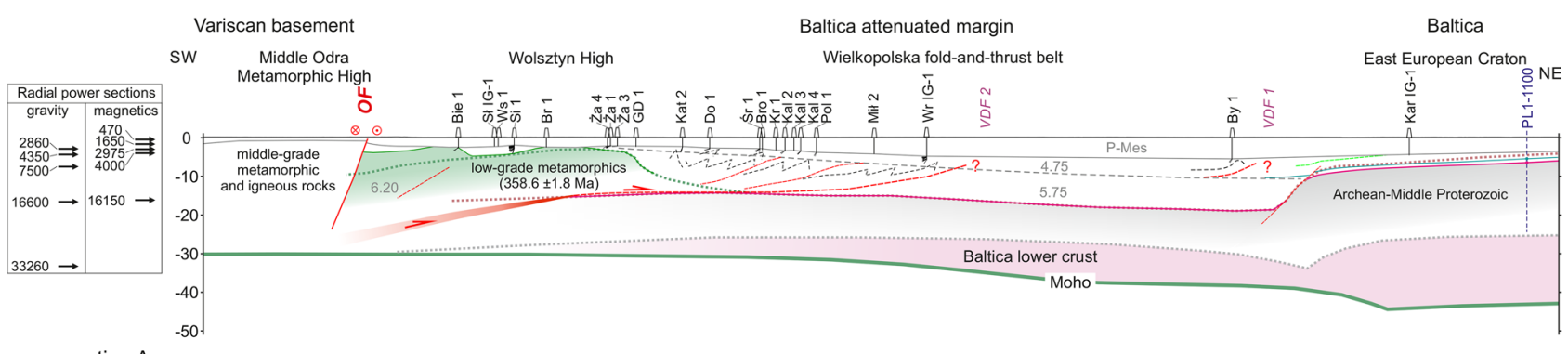

cross-section A

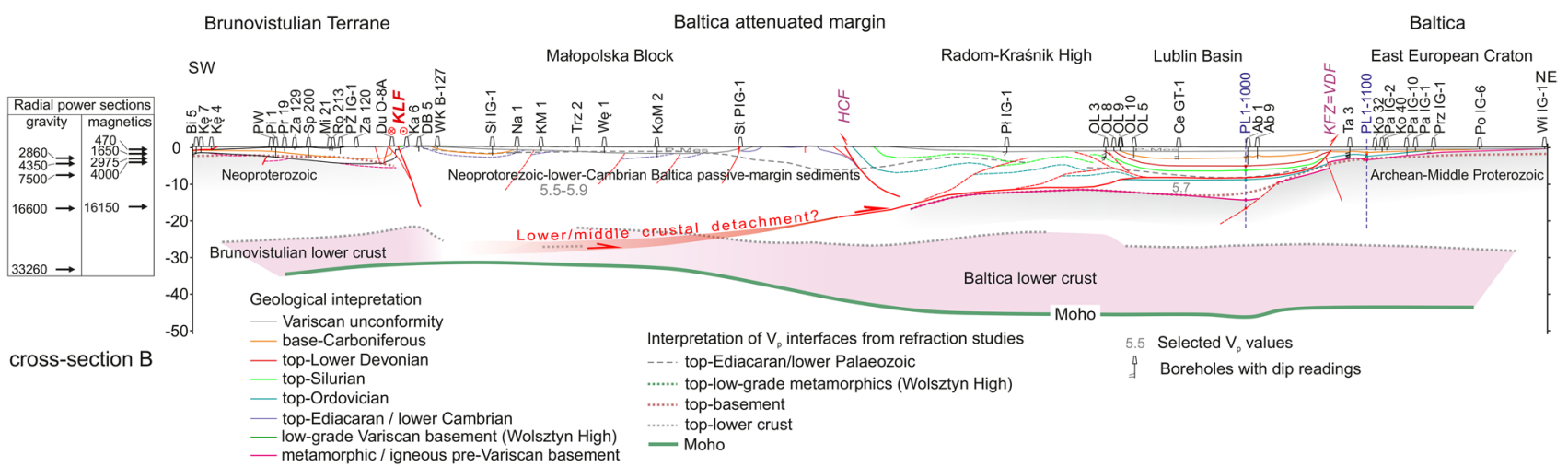

Fig. 8 Regional cross-sections through the eastern part of the Variscan belt in Poland. For locations see Fig. 2. Abbreviated borehole names (numbers omitted): $A b$ Abramów, Bi Bielsko, Bie Bielawy, Br Brenno, Bro Brodnica, By Byczyna, Ce Celejów, DB Dolina Będkowska, Do Donatowo, Du Dubie, GD Górka Duchowna, Ka Karniowice, Kal Kaleje, Kar Karnkowo, Kat Katarzynin, Kę Kęty, KM Kalina Mała, Ko Kolechowice, KoM Kostki Małe, Kr Krajkowo,

deformations embrace the whole Carboniferous subcrop reaching at least to the Byczyna 1 well (VDF 1 in the crosssection A). A similar reasoning was used by (Pożaryski et al. 1992) to trace their version of the Variscan deformation front (Fig. 3). On the other hand, Malinowski et al. (2007) placed a thin-skinned deformation front north of the Września IG-1 borehole using seismic data, although of a questionable quality (VDF 2 in cross-section A). Deformation of the Carboniferous series in the Byczyna 1 well would have to be related e.g. to the Variscan far-field basement deformation or Alpine inversion of the German-Polish Basin. Available subsurface data are insufficient to univocally pin the Variscan deformation front and from this point of view both versions of the Variscan deformation front marked in cross-section $\mathrm{A}$ are admissible.

The Wolsztyn High forms a hinterland backstop of the fold-and-thrust belt. This unit is built of low-grade slates that were drilled by several boreholes. For example, the Bielawy-1 well projected onto cross-section A penetrated a thin interval of Carboniferous flysch and then c. $150 \mathrm{~m}$ of phyllites down to the TD. The peak metamorphic age of these low-grade rocks is constrained at $358.6 \pm 1.8 \mathrm{Ma}$ (Mazur et al. 2006b) and protolith age remains unknown.
Mi Mirów, Mit Miłosław, $\mathrm{Na}$ Nasiechowice, $\mathrm{OL}$ Opole Lubelskie, $\mathrm{Pa}$ Parczew, Pi Piotrowice, Pt Płusy, Po Podedwórze, Pol Polwica, Pr Przeciszów, Prz Przewłoka, $P W$ Polanka Wielka, $P Z \dot{Z}$ Poręba Żegoty, Ro Rozkochów, Si Siciny, St Słomniki, Sła Sława, Sp Spytkowice, St Straszniów, Śr Śrem, Ta Tarkawica, Tr Trzonów, We Węchadłów, $W i$ Wisznice, $W K$ Wola Kalinowska, Wr Września, Ws Wschowa, Za Zator, Zal Zalas, Ża Żakowo

The Wolsztyn High apparently overlies the thinned EEC crust and this indicates its horizontal emplacement over the Baltica's margin. Carboniferous clastics occur in a transgressive position on top of the Wolsztyn High e.g. in the boreholes Bielawy 1 and Święciechowa 1. This marks a backstepping of the foreland basin onto the hinterland. According to Mazur et al. (2010), the Carboniferous series contain a significant detrital signature of a Late Devonian source, in line with the erosion and subsequent burial of the Wolsztyn High. Farther SW, the Odra Fault brings middle-grade and igneous rock of the Variscan hinterland to the shallow subcrop (e.g. Oberc-Dziedzic et al. 1999; Dörr et al. 2006). The Variscan crystalline units are depicted jointly as their internal structure is beyond the scope of this paper.

Internal geometry of the fold-and-thrust belt, in particular the position of its sole thrust, degree of tectonic stacking, and coupling with its metamorphic hinterland remain underconstrained as there is no unique structural solution to the sparse data. Despite of this, a series of geological and geophysical proxies help to narrow down the margin of uncertainty. No pre-Carboniferous rocks have been drilled at the base-Permian unconformity despite of folding/imbrication of Carboniferous series, and locally very dense borehole 
coverage. It may be due to the stratigraphic position of the sole thrust within the Carboniferous strata. A deeper detachment is equally admissible, provided low displacements of particular thrust or/and low ramp angles that would preserve pre-Carboniferous units below the Variscan unconformity. The Carboniferous series correspond to a distinct velocity domain of $4.75 \mathrm{~km} / \mathrm{s}$ (Grad et al. 2003). This velocity is characteristic of well-compacted clastics, in agreement with the dominant flysch lithologies. The interval is, however, relatively thin and thickens towards the foreland, opposite to a typical wedge-like cross-sectional geometry of fold-and thrust belts. Below, there is a $5.75 \mathrm{~km} / \mathrm{s}$ layer, interpreted as pre-Carboniferous Baltica's passive margin sedimentary cover (Grad et al. 2003). Notably, similar velocities of $5.5-5.9 \mathrm{~km} / \mathrm{s}$ occur in exposed, drilled, or well seismically resolved Ediacaran-lower Cambrian clastics in the Małopolska Block and Lublin Basin along the CEL02 profile (cross-section B) that strengthens this interpretation. A rise of the top of this interval towards the Wolsztyn High to 2-3 km b.s.l. may indicate a tectonic involvement of the preCarboniferous in the internal part of the fold-and-thrust belt. A trajectory of the sole thrust towards either version of the Variscan thin-skinned deformation front (VDF 1 and VDF 2 in the cross-section A) is unknown. In particular, whether it passes into an intermediate detachment in the Carboniferous or remains within the pre-Carboniferous stratigraphy until reaching the frontal ramp.

\section{Cross-section B}

The Palaeozoic basement along cross-section $\mathrm{B}$ remains shallow as compared to cross-section A (Fig. 8). Maximum thickness of the Permian-Mesozoic merely exceeds $1.5 \mathrm{~km}$ and there are two outcropping Palaeozoic inliers in the Holy Cross Mountains and Kraków areas. This, together with recently published seismic data, provides a relatively good insight into the pre-Permian geometries.

The frontal units of the Variscan belt in SE Poland are the Lublin Basin and the Radom-Kraśnik High. Their internal structure is depicted according to (Antonowicz et al. 2003; Krzywiec et al. 2017a, b; Tomaszczyk and Jarosinski 2017; Mazur et al. 2018; Kufrasa et al. 2019). A wealth of seismic data presented in these papers supports a thin-skinned deformation style above a continuous slope of the EEC. The top of the crystalline basement of the EEC along the section line is hard-constrained by Wisznice-1, Parczew IG-10 and Tarkawica-3 wells in the extreme NE. Intersections with the PolandSPANTM PL1-1000 and PL1-1100 lines provide additional ties in the Lublin Basin. The velocity interface in the CEL02 profile interpreted as the top-basement by Malinowski et al. (2005) is situated at $12-15 \mathrm{~km}$ b.s.l. in the Lublin Basin, rising towards the Radom Kraśnik High (Fig. 8). The large top-basement depth and its NE dip seems to be anomalous and the Ediacaran-Ordovician section marked by the $5.7 \mathrm{~km} / \mathrm{s}$ velocity is unusually thick as compared to the nearby CEL01 seismic refraction survey (Środa et al. 2006) and reflection surveys from surrounding areas (Krzywiec et al. 2017a, b; Kufrasa et al. 2019). A reason of this apparent discrepancy is a $6 \mathrm{~km}$ deep Neoproterozoic halfgraben identified by Krzywiec et al. (2018) in the PL1-1000 seismic line. Intersection of cross-section B with the PL11000 line falls very close to half-graben axis where the topbasement is at $\sim 16 \mathrm{~km}$ b.s.l. This is $\sim 2 \mathrm{~km}$ deeper than the top-basement velocity interface in the CEL02 line at this location. While a 3D geometry of this half-graben is not constrained, a deep position of the refraction top-basement in the CEL02 line under the entirety of the Lublin Basin suggests it may be a strike- or strongly oblique cut. A normal fault of the half-graben, possibly intersecting the section at a very low angle, has been conceptually placed, where the refraction top-basement rises steeply NE. SW from the tie provided by the PL1-1000 line, the top-basement in crosssection B follows the refraction top-basement. It regains its SW dip under the frontal part of the Radom-Kraśnik Block and descends continuously to more than $20 \mathrm{~km}$ b.s.l. below the Małopolska Block.

The Variscan deformation front emerges as the Kock Fault Zone interpreted as a thin-skinned ramp triggered by a basement step (Krzywiec et al. 2017a, b; Tomaszczyk and Jarosiński 2017). The Lublin Basin is a passive syncline detached and displaced NE along a detachment in the Silurian series. A stack of thrust sheets detached near a basement-cover interface and involving a thick Neoproterozoic-upper Palaeozoic sedimentary pile forms the RadomKraśnik High. As no direct constrains on the subsurface geometries exist along cross-section $\mathrm{B}$, the geometry is conceptual, reproducing the tectonic style known from the surrounding areas (Krzywiec et al. 2017a, b). The minimum thin-skinned shortening in the Radom-Kraśnik Block and Lublin Basin is estimated at $\sim 15$ to $20 \mathrm{~km}$. The shortening has been transferred from the SW which testifies to the Variscan emplacement of the Małopolska Block onto the margin of the EEC (Krzywiec et al. 2017b).

Variscan deformation in the Małopolska Block involves Ediacaran-lower Cambrian substrate and highly incomplete and discontinuous post-lower Cambrian Palaeozoic cover. Notably, middle-upper Cambrian and Ordovician-Silurian are nearly entirely missing apart from the Holy Cross Mountains, where a less eroded NE margin of the Małopolska Block crops out. Long wavelength folds or fault blocks define first-order structural fabric; relatively low density of boreholes does not permit differentiating between tectonics styles. It is also likely that the density of lower-order structures is underestimated for the same reason. Detachment must be located within the Neoproterozoic sediment pile or within the basement, possibly in the middle/lower crust. The 
latter possibility is supported by the deep reflection survey POLCRUST-01 (Malinowski et al. 2013) that shows strong yet discontinuous and vertically offset reflectors in the deep subsurface of the Małopolska Block. The two scenarios, however, do not mutually exclude one another.

The Brunovistulian Terrane is a coherent crustal block with a shallow top-basement and distinct velocity structure contrasting with that of the Małopolska Block (Malinowski et al. 2005). It features a Cadomian basement (Żelaźniewicz et al. 2009) and discontinuous Palaeozoic cover, largely lacking a lower Palaeozoic section. The two units are separated by the Kraków-Lubliniec Fault the Brunovistulian side of which is less eroded than the Małopolska side. This suggests a NE dip of the fault zone although alternative solutions are also possible given no direct control on the fault geometry. The top-basement of the Brunovistulian Terrane is hard-constrained by the Kęty 7 borehole in the extreme SW of the cross-section. Borehole data suggest deepening of the basement towards the Kraków-Lubliniec Fault, a trend confirmed by the refraction top-basement.

\section{Along-strike correlation}

Comparison of cross-sections A and B reveals similarities but also some profound differences in the geometry and crustal-scale components of the Variscan belt on both sides of the presumed oroclinal bend. Primarily, both sections show a thin-skinned deformation front: vaguely constrained in the cross-section A and well constrained in the cross-section B. Is it the same deformation front crossing Poland from the NW to SE or two independent features separated by the oroclinal loop of the fold-and-thrust belt? A map of maximum dips recorded in cores from Carboniferous and Devonian strata approximates a distribution of Variscan deformations and delineates potential foreland areas; hence, it helps to delineate a Variscan deformation front between the two cross-sections (Fig. 9). Moderate to steep dips predominate across- and along-strike of the Devonian-Carboniferous subcrop over the entire area between the two cross-sections and beyond. Boreholes with lower dips are less common and concentrate over the Wolsztyn High, where the Carboniferous is less deformed owing to its transgressive position on top of the Variscan low-grade basement. A belt of low to subhorizontal dips stretches only along the NE perimeter of the Devonian-Carboniferous subcrop (Fig. 9). We interpret this zone as the NE Variscan foreland beyond the reach of the Variscan thin-skinned deformation. Therefore, out of the two extreme positions of the Variscan deformation front marked in cross-section A (Fig. 8), we favour the most distal one labelled VDF 1 in Fig. 8 and VDF in Fig. 9. This solution is also compatible with the results of processing of gravimetric and magnetic data presented before. Importantly, there is no signature of an N-S striking foreland along any of the "oroclinal" versions of the Variscan deformation front. Instead, there exists an uninterrupted zone of steep dips crossing the presumed N-S branch of the Variscan foldand-thrust belt. This is consistent with the NE-SW trending gravimetric and magnetic fabric (Fig. 6) and suggests a certain degree of tectonic continuity between the Variscan structures in $\mathrm{W}$ and SE Poland.

Despite of the common NW-SE trending deformation front, the crustal-scale configurations of the Variscan belt along cross-sections A and B are markedly different. The Variscides in SE Poland (cross-section B) are missing an orogenic core. The entire assemblage consists of pre-Variscan basement units overlain by deformed but non-metamorphosed Palaeozoic rocks. Conversely, there are no pre-Variscan crustal blocks (e.g. the Brunovistulian Terrane) embedded in the external Variscides of W Poland (cross-section A). Instead, there is a prominent metamorphic hinterland and a Carboniferous fold-and-thrust belt that jointly produce a fairly regular structural zonation of a collisional orogen. In consequence, while the external zone of the Variscan orogen seems to parallel the NW-SE trending margin of the EEC as indicated by the gravimetric and magnetic patterns, the internal zones must envelope the Brunovistulian Terrane from the $\mathrm{W}$ and $\mathrm{S} / \mathrm{SW}$. The difference coincides with an abrupt vs stepwise thinning of the EEC crust along cross-sections $\mathrm{A}$ and $\mathrm{B}$ that is a plausible reason for a closer advance of the internal Variscan units towards the EEC in W than in SE Poland. Another consequence of the different anatomies of the Variscan belt in W and SE Poland is a question of continuity of the Odra and KrakowLubliniec Faults (cross-sections A and B, respectively; Fig. 2). Although aligned in the map-view, these important faults are difficult to correlate: the former separates lowand medium-grade Variscan units, while the latter forms a boundary between the pre-Variscan Brunovistulian Terrane and Małopolska Block. If both faults are the same structure, it would have to postdate an emplacement of the Variscan metamorphic units of W Poland (cross-section A). One may also hypothetically consider the Kraków-Lubliniec and Odra Faults an expression of the distal edge of Balticaoverridden by Variscan orogen in W Poland (cross-section A) and largely preserving its pre-Variscan configuration in SE Poland (cross-section B).

\section{Main tectonic features from maps and literature}

\section{Major WNW-ESE Variscan strike-slip faults in the Sudetes and beyond}

A number of NW-SE-oriented major late Carboniferous to Permian strike-slip faults with dextral kinematics, 


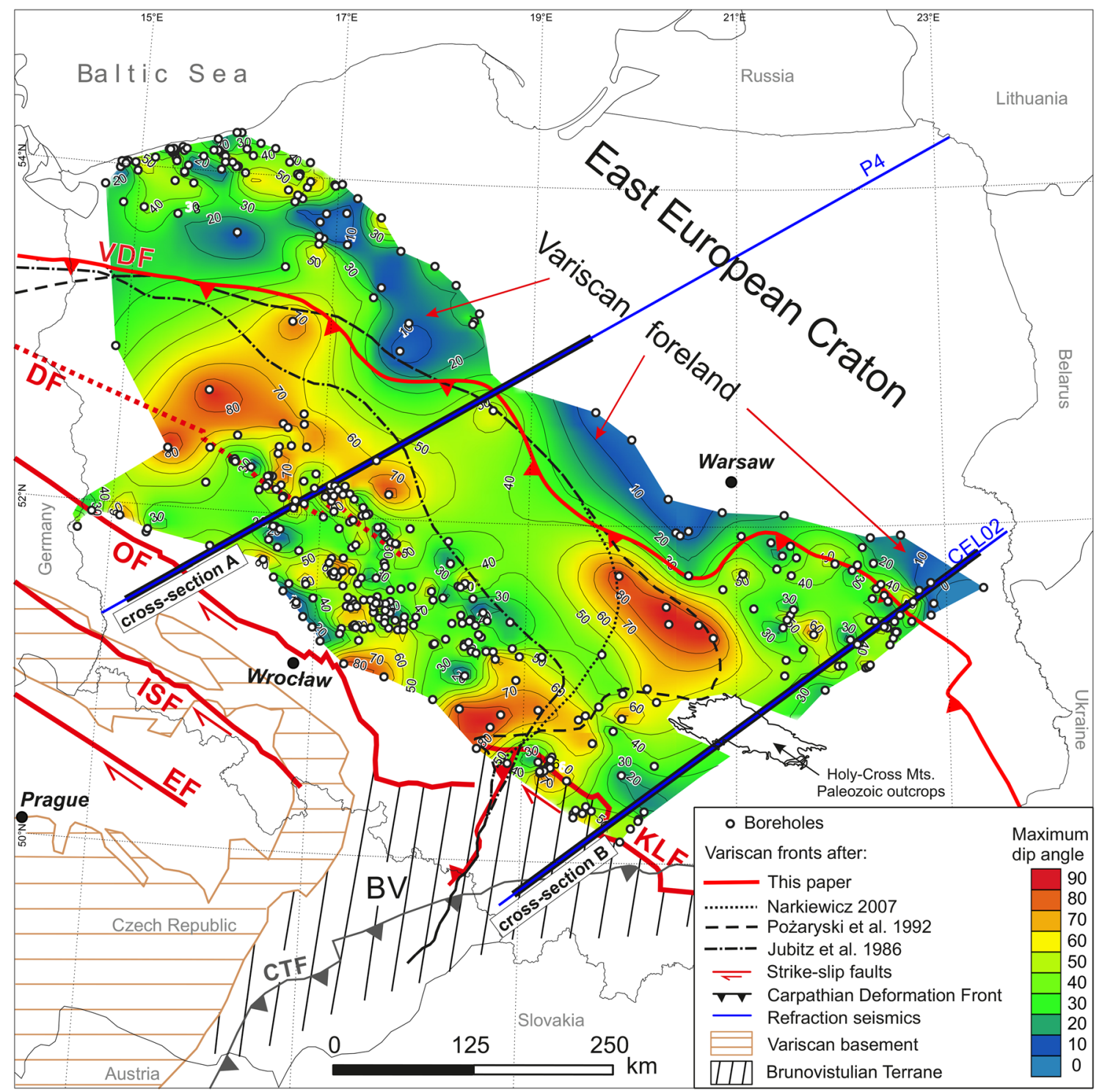

Fig. 9 Distribution of maximum dip angles in the Devonian-Carboniferous succession of the external zone of the Variscan orogen in Poland. $V D F$ admissible trace of the Variscan deformation front in W Poland

accompanied by smaller-scale sinistral complementary counterparts, were postulated by Arthaud and Matte (1977) around the Bohemian Massif and in SW Poland and eastern Germany within the frame of a mega-shear zone extending between the Urals and the Appalachians. In particular, they named the 'Elbe fracture', one stretch of which correlates with the Middle Odra Fault Zone at the northern foreland of the Sudetes, and a successive one with the Kraków-Lubliniec Fault farther east (Fig. 2). The location, structural characteristics and dating of major strike-slip faults/shear zones in the Sudetes and their surroundings were the subject of later investigations focusing on details of regional geology (e.g. Aleksandrowski 1990,
1995; Aleksandrowski et al. 1997; Żaba 1999; Aleksandrowski and Mazur 2002).

\section{The Upper Elbe Fault}

The Upper Elbe Fault Zone (not to be confused with the Elbe Lineament or Elbe fracture mentioned earlier) is probably the best-known strike-slip feature within the Bohemian Massif, separating the Sudetes from the core of the massif (Figs. 2, 10). It can be traced from the NW vicinities of Dresden (Gotte and Hirschmann 1972; Mattern 1996) gradually increasing the dextral displacement to $15-20 \mathrm{~km}$ near Dresden and 100-120 km SE of the Elbe River (Rajlich 1987, 1990a; Aleksandrowski 1995). The passive markers that can 


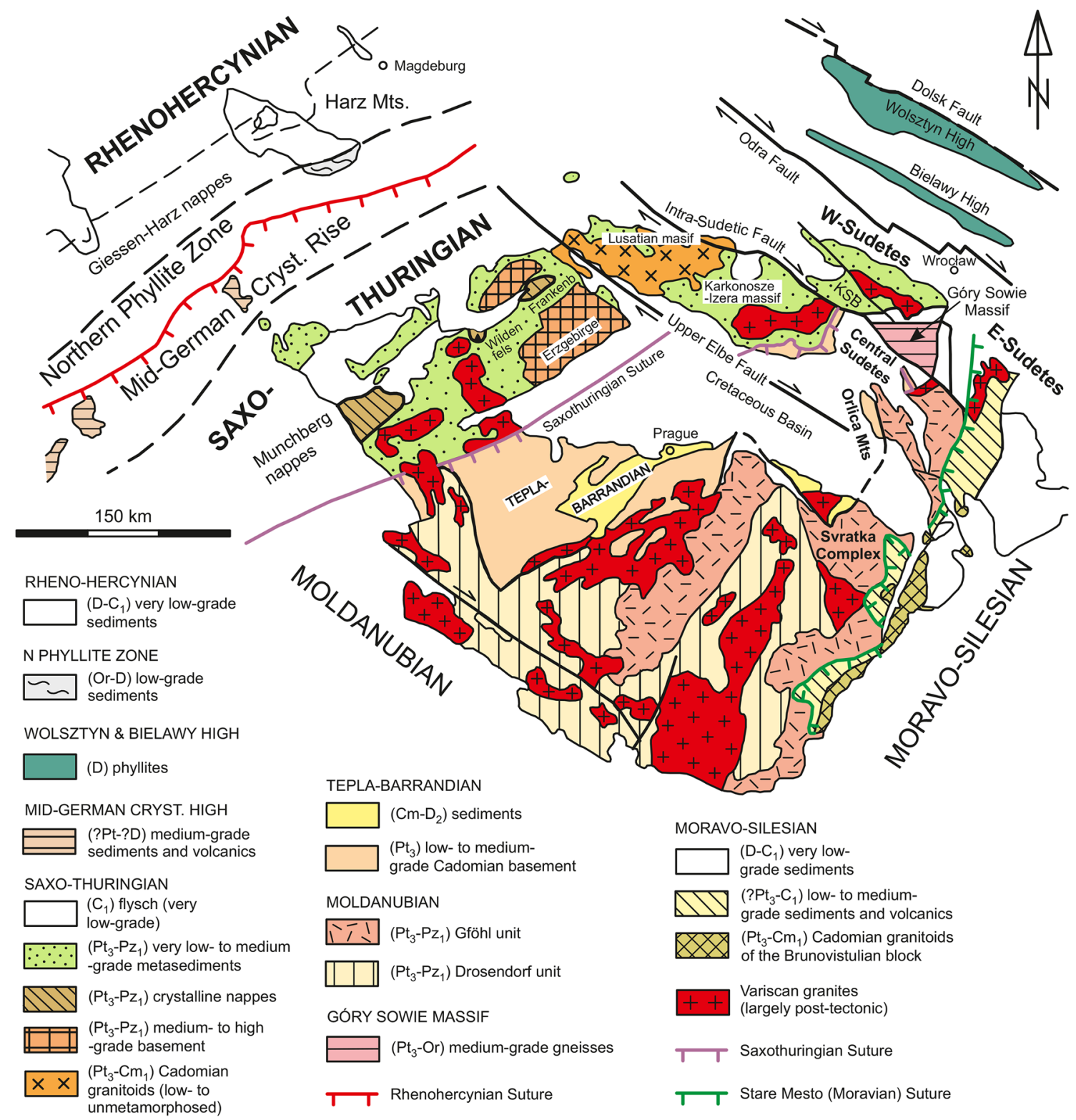

Fig. 10 Variscan suture zones and major strike-slip faults overlaid on the tectonostratigraphic division of the Bohemian Massif (modified from Franke et al. 2017, following Kossmat 1927). KSB Kaczawa

be used to determine a magnitude of movement along the fault are mutually displaced outcrops of the Izera and Erzgebirge gneisses as well as discontinuous magnetic anomalies (Rajlich 1987, 1990a). A similar amount of dextral offset is also suggested by the displacement of the Saxothuringian Suture (separating the Saxothuringian and Teplá-Barrandian Zones) between the Erzgebirge and the Karkonosze-Izera Massif (Figs. 2, 10) as postulated by Mazur and Aleksandrowski (2001) and Konopásek et al. (2019). Since the displacement along the Upper Elbe Fault decreases toward the boundary of the Rhenohercynian Zone the fault may have been a transfer feature, whose offset decreases along with
Slate Belt. Age assignments: $P t$ Proterozoic, $P z$ Palaeozoic, $\mathrm{Cm}$ Cambrian, Or Ordovician, $D$ Devonian, $C$ Carboniferous, 1 Early, 2 Middle, 3 Late

the northward younging of deformation (Franke et al. 2017). The Upper Elbe Fault is concealed by the Cretaceous North Bohemian Basin farther SE and its existence at the eastern margin of the Bohemian Massif is uncertain (Fig. 10). However, there is a possible connection between the exposed part of the Upper Elbe Fault and the dextral fault that displaces the Železné Hory against the western, exposed part of the Teplá-Barrandian. 


\section{The Intra-Sudetic Fault}

The most conspicuous Variscan structural discontinuity in the Polish Sudetes is the WNW-ESE trending IntraSudetic Fault (Berg 1913; Oberc 1964; Don 1990; Aleksandrowski 1990, 1995; Aleksandrowski et al. 1997). It relates to a few hundred meters wide zone of ductile and semi-ductile deformation zone (Aleksandrowski et al. 1997). The fault, together with its NW extension into Germany, the Main Lusatian Fault, define a roughly rectilinear, c. $300 \mathrm{~km}$ long, trace in map view (Figs. 2, 10). None of the tectonic units present in the Sudetes directly continues across the Intra-Sudetic Fault (Fig. 10). The apparent dissimilarity of geological features on both sides of the Intra-Sudetic Fault, with its SW flank heavily affected by early Carboniferous collisional processes, suggests an important lateral displacement along the fault. However, the scale of offset cannot be unequivocally calculated.

Matte et al. (1990) consider the Intra-Sudetic Fault as a late Carboniferous dextral feature with the displacement magnitude of the order of a few tens of kilometres. According to Aleksandrowski $(1990,1995)$ and Aleksandrowski et al. (1997), the late Devonian(?)-early Carboniferous dextral displacement on this fault/ductile shear zone may have possibly reached up to c. $300 \mathrm{~km}$, preceding its late Carboniferous reversal and the related sinistral displacement in semi-brittle conditions by c. $10-15 \mathrm{~km}$. The former displacement may have removed the Kaczawa Slate Belt and Góry Sowie Massif from their possible original locations within the Northern Phyllite and Saxothuringian Zones, respectively (Fig. 10). Franke and Żelaźniewicz (2002) proposed that the Intrasudetic Basin represents a pull-apart basin formed along the Intra-Sudetic Fault, so that the extent of that basin in the WNW-ESE direction would equal the amount of displacement $(\sim 70 \mathrm{~km})$. This is partly in accord with suggestions by Suess (1926), Kossmat (1927), Behr et al. (1982) and Franke et al. (1993), who envisaged the Góry Sowie Massif as originally aligned with the Münchberg, Frankenberg and Wildenfels Massifs as later confirmed by analysis of gravity maps (Edel and Weber 1995). Furthermore, after subtracting $100 \mathrm{~km}$ of dextral displacement along the Elbe Fault, the actual offset along the Intra-Sudetic Fault might have been significantly lower than originally postulated in its maximum version (Aleksandrowski 1995) to allow the correlation between Münchberg and Góry Sowie. Regardless of the actual size of the displacement, the Intra-Sudetic Fault disappears at the eastern margin of the Bohemian Massif (Fig. 10). It is possible that the fault splits in a few splays north of the Orlica-Śnieżnik Dome before reaching the Moravo-Silesian Zone (Oberc 1991). Alternatively, the Intra-Sudetic Fault may have been cut off by younger, N-Soriented displacements within the Moravo-Silesian Zone, at the boundary with the Brunovistulian terrane. Sinistral strike-slip displacements along the Moravo-Silesian Zone, preceding those of dextral sense (Rajlich 1987, 1990a; Aleksandrowski 1995) may have transferred it northward by c. $40 \mathrm{~km}$ to the position $\mathrm{SW}$ of the NW end of the Kraków-Lubliniec Fault (Figs. 5, 7, 11). In such a case, the Intra-Sudetic Fault may have had its twice-displaced continuation in the Kraków-Lubliniec Fault Zone.

\section{Middle Odra Fault}

The Middle Odra Fault is a complex fault zone, representing a stretch of the 'Elbe fracture' of Arthaud and Matte (1977), that defines the NE boundary of the known extent of Variscan crystalline basement of the Sudetes (Figs. 2, 8, 10) and is entirely concealed beneath Mesozoic and younger rocks. The non-metamorphosed Carboniferous flysch sediments of the Variscan externide belt are in contact, across this fault, with southerly located medium-grade gneisses and schists intruded by several granite plutons of early Carboniferous age (Oberc-Dziedzic et al. 1999; Franke and Żelaźniewicz 2000, 2002; Dörr et al. 2006). This section of the Variscan basement has been compared in the past with the Mid-German Crystalline Rise (e.g. Ellenberger and Tamain 1980; Dörr et al. 2006), the hypothesis that is admissible, but not fully confirmed based on the data available. The flysch succession north of the Middle Odra Fault is buried below the extensive Permian-Mesozoic sequence of the German-Polish Basin that attains $1 \mathrm{~km}$ of thickness near the contact with the Variscan basement and becomes gradually thicker northward. Consequently, an important post-Variscan dip-slip component of displacement along the Middle Odra Fault is proved. Apart from that, no other information on kinematics of the fault is available. Nevertheless, owing to an alignment with the Kraków-Lubliniec Fault (Fig. 2), kinematic data from the latter might be, albeit with restrictions raised in Sect. 4.3, extrapolated to the Middle Odra Fault, especially as concerns late Carboniferous and younger displacements.

\section{Kraków-Lubliniec Fault}

The Kraków-Lubliniec Fault delineates a boundary between the Upper Silesian Block (the northern segment of the Brunovistulian Terrane) and the Małopolska Block that represents the non-metamorphic basement to the Palaeozoic Platform in SE Poland (Fig. 2; Buła et al. 1997; Żaba 1999, Buła 2000). The fault coincides with a subvertical discontinuity in the P-wave velocity model of the CEL-02 seismic refraction profile reaching down to the lower crust (Malinowski et al. 2005).

The Kraków-Lubliniec Fault is associated with a c. $500 \mathrm{~m}$ wide zone of semi-ductile and brittle deformation (Żaba 1999; Buła 2000). Folding prevails in Ediacaran to 


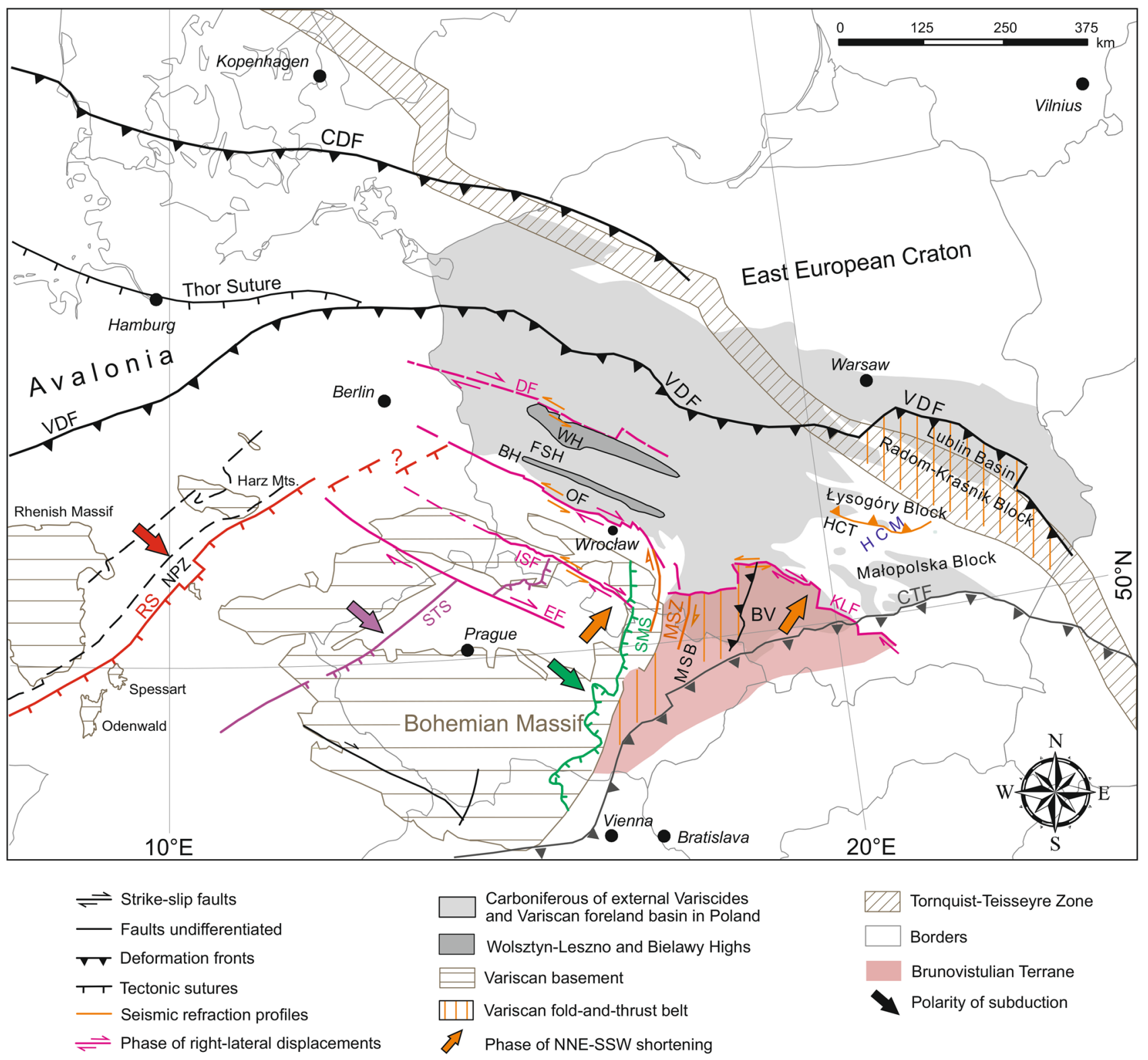

Fig. 11 Generalized kinematic model for a junction between the Variscan belt and its NE foreland. Two post-collisional phases of deformation are indicated: dextral wrenching and NNE-SSW shortening. A uniform SW polarity of subduction prior to the early Carboniferous collision is also shown. $B H$ Bielawy High, $B V$ Brunovistulian terrane, $C D F$ Caledonian deformation front, $C T F$ Carpathian thrust front, $D F$

Palaeozoic cover sequences at the margin of the Brunovistulian Terrane, whereas brittle tectonics predominates within the adjacent part of the Małopolska Block (Żaba 1999). The fault crosscuts and offsets all Palaeozoic and older rock complexes, including the Permian (Buła et al. 1997; Żaba 1999; Buła 2000). Strike-slip displacements dominated during the polyphase structural evolution of the Kraków-Lubliniec Fault with 3 major deformation events (Żaba 1999): (1)
Dolsk Fault, EF Upper Elbe Fault, HCM Holy Cross Mountains, HCT Holy Cross Thrust, ISF Intra-Sudetic Fault, KLF Kraków-Lubliniec fault, $M S B$ Moravo-Silesian belt, MSZ Moravian Shear Zone, NPZ Northern Phyllite Zone, OF Odra Fault, RS Rhenohercynian Suture, SMS Staré Město (Moravian) Suture, STS Saxothuringian Suture, $V D F$ Variscan Deformation Front, $W H$ Wolsztyn High

sinistral transpression at the transition from Silurian to Devonian, (2) dextral transpression in late Carboniferous with an interlude of dextral and, locally, also sinistral, transtension, and (3) sinistral transpression in early Permian. In addition, vertical displacements played an important role, especially in the Late Devonian and early Carboniferous (Żaba 1999). 
The contact zone between the Małopolska Block and Brunovistulian Terrane is penetrated by numerous igneous bodies of various age (Silurian to Permian) and composition (granites, porphyritic dacites, rhyolites, and minor mafic dykes; Żaba 1999; Słaby et al. 2010). The peak of magmatic activity occurred at the transition from Carboniferous to Permian times (Żaba 1999; Żelaźniewicz et al. 2008; Nawrocki et al. 2010).

\section{Dolsk Fault}

Basement rocks underlying the Carboniferous flysch succession north of the Odra Fault remain generally unknown, except for two minor WNW-ESE-trending crystalline highs (Figs. 2, 10). The larger of these, the Wolsztyn High, consists of phyllites that underwent low-grade metamorphism, the timing of which is constrained by a white mica ${ }^{40} \mathrm{Ar} /{ }^{39} \mathrm{Ar}$ cooling age of $358.6 \pm 1.8 \mathrm{Ma}$ (Mazur et al. 2006b). The NE boundary of the Wolsztyn High is defined by the Dolsk Fault, whose sub-vertical geometry is inferred from a combination of seismic and well data (Dadlez 2006; Kiersnowski et al. 2010). On the P-4 seismic refraction profile (Grad et al. 2003), the Dolsk Fault corresponds to a boundary between the low-velocity Variscan-type upper and middle crust to the SW and the three-layer crust underlying the Palaeozoic Platform in the NE (e.g. Grad et al. 2003).

\section{Polarity of convergence within the Sudetic internides}

A characteristic feature of the Sudetes, already mentioned in the introduction chapter, is the NW-SE oriented structural grain that contrasts with the most part of the Variscan belt extending SW-NE across Western Europe (Fig. 1). The latter area reveals NW- or SE-ward tectonic polarity during successive phases of terrane accretion resulting from closure of the Rheic and, then, the Rhenohercynian, Saxothuringian and Galicia-Moldanubian Oceans (e.g. Franke 2000; Franke et al. 2017; Edel et al. 2018). The change of a structural trend at the eastern termination of the Variscides was often evoked in favour of the Variscan orocline in Central Europe based on the assumption of post-collisional bending (e.g. Tait et al. 1996, 1997).

In some localities of the Moravo-Silesian Zone, Krs and Pruner (1995) and Tait et al. (1996) identified a magnetization direction that was interpreted by Tait et al. (1996) as a primary Devonian magnetization indicating large clockwise rotations during the Variscan orogeny. Consequently, Tait et al.'s $(1996,1997)$ results were considered to support oroclinal bending around the NE flank of the Bohemian Massif. The orocline hypothesis was questioned by Edel et al. (2003), who claimed that the Moravo-Silesian magnetization is a late Carboniferous overprint and that in the Devonian and early Carboniferous, the Bohemian Massif was too weakly consolidated to act as an indenter (Edel et al. 2003). In addition, relatively high thermal maturity of the MoravoSilesian Devonian carbonates (Krs et al. 1995) implies that preservation of a primary magnetization is rather unlikely. The more recent study by Grabowski et al. (2008) did not confirm the presence of primary magnetization, previously reported from the carbonate rocks of the Moravo-Silesian Zone (Krs and Pruner 1995; Tait et al. 1996). The oldest magnetization component that was believed to justify large tectonic rotations in the Moravo-Silesian Zone (orocline hypothesis; Tait et al. 1996, 1997) reveals a synfolding geometry and it may represent an early Carboniferous overprint (Grabowski et al. 2008). The occurrence of sub-parallel paleomagnetic directions in the Moravo-Silesian Zone (Grabowski et al. 2008), central Bohemian Massif and Palaeozoic massifs of Western Europe implies common clockwise rotation phases during the middle-late Carboniferous (Edel et al. 2003, 2018).

Several recent tectonic models for the Bohemian Massif postulate NW-SE convergence of the Saxothuringian, Teplá-Barrandian and Brunovistulian Terranes due to subduction and subsequent Variscan collision (e.g. Schulmann et al. 2009, 2014; Lexa et al. 2011; Chopin et al. 2012; Žák et al. 2014). This is also the case for the Sudetes, where NW-vergent regional-scale nappe stacking was demonstrated in some areas (Seston et al. 2000; Mazur and Aleksandrowski 2001; Mazur et al. 2004, 2006a, 2015a, b; Konopásek et al. 2019) and the Saxothuringian Suture shown to extend roughly NNE-SSW along the eastern Karkonosze-Izera Massif (Fig. 10; Mazur and Aleksandrowski 2001; Jeřábek et al. 2016). Furthermore, the western margin of the Brunovistulian Terrane, forming a backstop at the rear of the Sudetic accretionary prism, also extends NNE-SSW (Fig. 10; Chopin et al. 2012; Mazur et al. 2012; Janoušek et al. 2014). This geometry and structural kinematics are in line with the growth of the Orlica-Śnieżnik Dome due to eastward influx of a Saxothuringian-type passive margin sequence below a Teplá-Barrandian upper plate, as advocated by Chopin et al. (2012). Consequently, the section of the Sudetes located between the Upper Elbe and IntraSudetic Faults (Fig. 10) shows a NW-ward tectonic polarity, similar to that in the remaining parts of the Bohemian Massif and German Variscides.

The recognition of the tectonic polarity NE of the IntraSudetic Fault is less obvious. This is due to the fact that none of the Sudetic units west of the Brunovistulian Terrane, continues northward beyond the fault. In addition, the exposure of the Variscan basement is poorer in the northern part of the Sudetes. Nevertheless, the belt of outcrops between the Intra-Sudetic and Odra Faults reveals an increase in metamorphic grade towards the SE, with the Gory Sowie Massif in the south-easternmost position. This sequence can be 

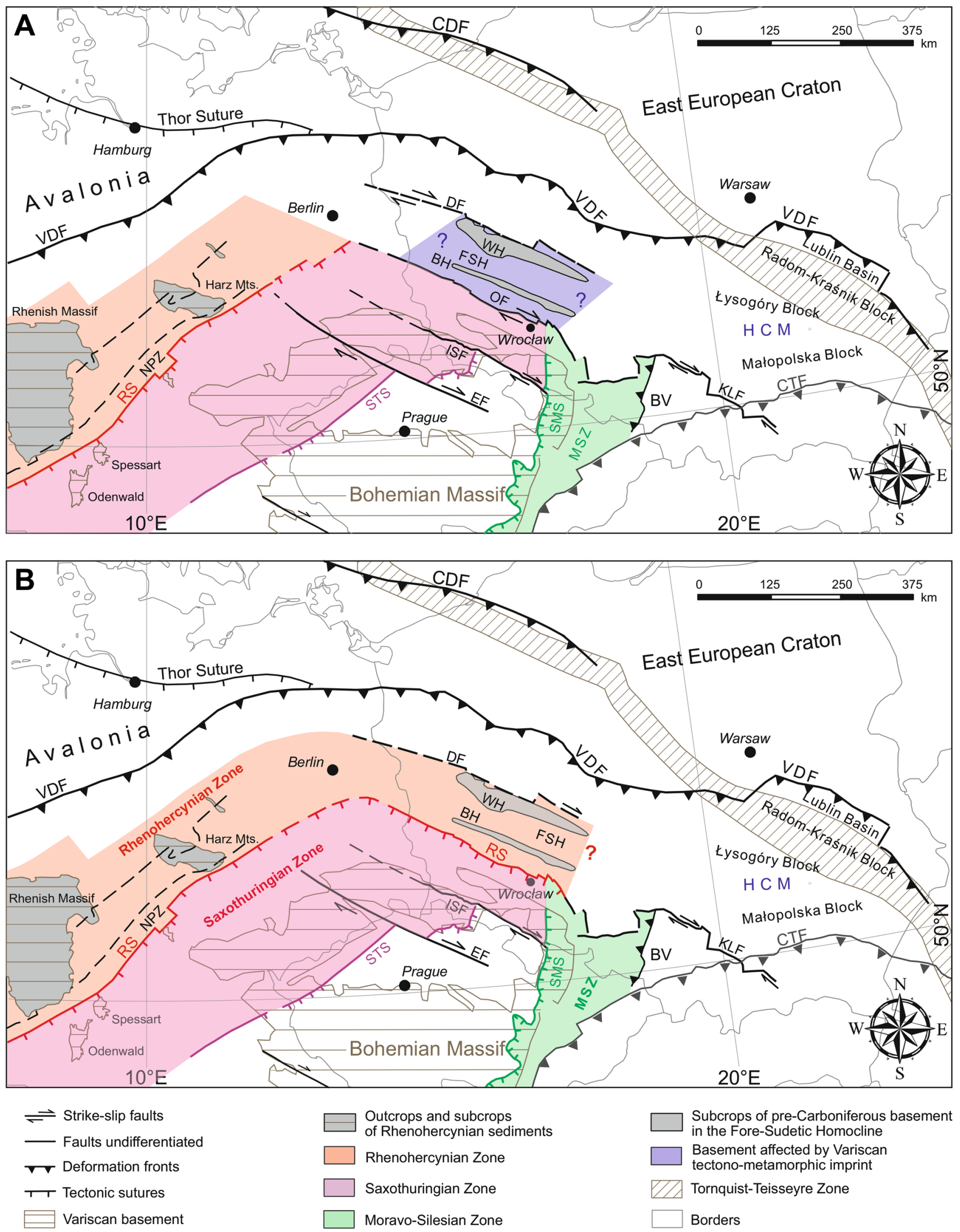
4Fig. 12 Two alternative models for the NE termination of the Variscan belt in Central Europe: a strike-slip tectonics and b semi-oroclinal $\left(\sim 90^{\circ}\right)$ bending. Basement of the Fore-Sudetic Homocline may represent a laterally displaced section of the Rhenohercynian Zone or another part of the Laurussian margin affected by the Variscan tectono-metamorphic imprint. $B H$ Bielawy High, $B V$ Brunovistulian terrane, $C D F$ Caledonian deformation front, $C T F$ Carpathian thrust front, $D F$ Dolsk Fault, EF Upper Elbe Fault, HCM Holy Cross Mountains, ISF Intra-Sudetic Fault, KLF Kraków-Lubliniec fault, $M S Z$ Moravo-Silesian Zone, NPZ Northern Phyllite Zone, OF Odra Fault, $R S$ Rhenohercynian Suture, SMS Staré Město (Moravian) Suture, STS Saxothuringian Suture, VDF Variscan Deformation Front, WH Wolsztyn High

interpreted to represent a tectonic stack with metamorphic inversion, tectonic boundaries dipping grossly toward the $\mathrm{SE}$ and the WNW-ward directed tectonic transport (Franke et al. 1993; Seston et al. 2000). Although their hypothesis is not fully substantiated by available evidence, it is consistent with the dominant WNW-ESE orientation of stretching lineation that is identical on both sides of the Intra-Sudetic Fault (e.g. Aleksandrowski and Mazur 2002). Consequently, at the present state of the art, there is no factual evidence for a diverse convergence polarity within the Sudetes compared to the remaining part of the Variscan belt.

\section{The Variscan deformation front in Poland}

The location of the Variscan deformation front in Poland beneath the Permian-Mesozoic German-Polish Basin has been variously interpreted over the past decades (e.g. Jubitz et al. 1986; Pożaryski et al. 1992; Narkiewicz 2007). The two best-known interpretations (Jubitz et al. 1986; Pożaryski et al. 1992) both postulated oroclinal bending of the Variscan front in SW Poland, before reaching the Holy Cross Mts. located farther east (Fig. 3, $\operatorname{VDF}(A)$ and $\operatorname{VDF}(B)$, respectively). Jubitz et al. (1986) attached more weight to the facies characteristics of Carboniferous sediments. Their Variscan front largely outlines the extent of lower Carboniferous flysch. In contrast, Pożaryski et al. (1992) mostly based their interpretation on the distribution of Carboniferous (predominantly late Carboniferous) deformation. This, probably more appropriate, criterion was biased by a limited number of wells penetrating the Carboniferous strata. Numerous other papers and interpretations over the recent decades have presented solutions being a various type of compromise between these end member solutions (e.g. Dadlez et al. 1994; Mazur et al. 2006a; Narkiewicz 2007). Furthermore, all these interpretations were to some extent affected by the assumption made by their authors that "miogeosynclinal" areas as the Holy Cross Mts. and the SW slope of the East European Craton cannot be parts of the orogen per se (cf. Mazur et al. 2006a; Narkiewicz 2007; Konon 2008). Notably, until 1960s, based exclusively on exposures of pre-Permian rocks, an extension of Variscan deformations toward the Holy Cross Mts. and farther east was a commonly accepted interpretation (e.g. Bertrand 1887; Nowak 1927; Bederke 1930; Książkiewicz et al. 1965; but see also more recent interpretation by Ziegler 1990).

\section{The Variscides in SE Poland (Lublin Variscides)}

The occurrence of Variscan thin-skinned, compressional deformation structures east of the Holy Cross Mountains, over the Radom-Kraśnik Block and the Lublin Basin (Fig. 2) was first postulated by Antonowicz et al. (2003) and Antonowicz and Iwanowska (2004), i.e., in areas located far beyond the then generally accepted eastern extent of the Variscan fold-and-thrust belt (Figs. 2, 3; Jubitz et al. 1986; Pożaryski et al. 1992). Recently, combined POLCRUST-01 and PolandSPANTM deep seismic reflection surveys (Malinowski et al. 2013; Krzywiec et al. 2014) along with newly acquired industrial seismics (Krzywiec et al. 2017a, Tomaszczyk and Jarosiński 2017) imaged a Variscan thin-skinned foldand-thrust belt encroaching onto a little deformed basement slope of the EEC (Krzywiec et al. 2017a, b). This belt of thin-skinned deformation involves a number of sub-Permian tectonic units of Poland's Palaeozoic platform, to a various degree overprinted by Variscan shortening and inversion (cross-section 'B' in Fig. 8).

The seismic data show that the Radom-Kraśnik Block and the Lublin Basin represent a NE-vergent thin-skinned system overthrust toward the craton. The former unit is a thrust stack that imbricates a 10-12 km thick pile of Neoproterozoic to Devonian sediments. Its leading edge is a triangle zone related to the jump of the basal detachment from a basement-cover interface to Silurian shales. The passive roof of this triangle zone involves Carboniferous strata.

\section{Geometric and kinematic models}

\section{Strike-slip model}

The NE-SW to NNE-SSW orientation of the early Carboniferous sutures in the Sudetes (Saxothuringian and Staré Město Sutures) and a probable SE direction of preceding subduction (Fig. 11) suggest unchanged polarity of the Variscan belt from Germany to Poland. Such a configuration supports a strike-slip model for the eastern termination of the Variscan belt (Fig. 12a). This model is consistent with a coherent WNW-ESE orientation of structural grain in the Variscan foreland beneath a cover of Permian-Mesozoic strata (Figs. 5, 6, 7). Potential field data also reveal that the NNE-SSW Variscan sutures do not continue northward into the Variscan foreland (Fore-Sudetic Homocline; Figs. 3, 5, 7). This may mean that (1) the potential continuation of the sutures was laterally displaced, (2) the Variscan system in 
the Late Devonian-early Carboniferous was tectonically decoupled from its present-day northern foreland or both. Indeed, as already mentioned, the terranes of the Bohemian Massif were weakly consolidated before the late Carboniferous. In addition, the supposed subduction zones in the Sudetes were oriented at a high angle to the Laurussia margin. Therefore, the SW edge of Baltica may have formed a transform margin during the Late Devonian and earliest Carboniferous.

Strike-slip displacements in the Sudetes may have been related to a general dextral regime between Gondwana and Laurussia at the late stage of the Variscan orogeny (e.g. Arthaud and Matte, 1977). On the local scale of SW Poland and adjacent areas, the general lateral displacement between the supercontinents could have been conveyed by a set of mutually parallel crustal discontinuities, such as the Elbe, Intra-Sudetic, Odra, Dolsk and Kraków-Lubliniec Faults (Figs. 11, 12a). All these fault zones are consistently trending WNW-ESE, oblique at a low angle to the TeisseyreTornquist Zone. An episode of dextral strike-slip faulting occurred at the late stage or after cessation of the Variscan collision in the Sudetes (Figs. 11, 12a). The Saxothuringian Suture is dextrally displaced by $\sim 100 \mathrm{~km}$ along the Elbe Fault (Fig. 11), suggesting a post-subduction displacement. On the other hand, neither the Upper Elbe Fault nor the Intra-Sudetic Fault do not significantly displace the course of the Staré Město (Moravian) Suture (Fig. 11). This may suggest a retreat of a subduction slab at the western margin of the Brunovistulian Terrane (Janoušek et al. 2014, their Fig. 12), the situation analogous to the present-day Apennines (e.g. Royden 1993; Scrocca et al. 2007). This interpretation, though hypothetical, can be tested since the slab retreat should have caused a significant extension at the rear (i.e. eastward) of the Staré Město (Moravian) Suture.

The amount of displacement on the Intra-Sudetic Fault, terminating the Saxothuringian Suture from the north, remains uncertain. The correlation of the Góry Sowie Massif with the Münchberg, Widenfels and Frankenberg Massifs (Fig. 11; e.g. Franke et al. 1993; Martínez Catalán et al. 2020) would imply $200 \mathrm{~km}$ of the total net displacement $(\sim+100 \mathrm{~km}$ on the Intra-Sudetic Fault). The derivation of the Góry Sowie Massif from the Mid-German Crystalline High (Aleksandrowski 1990, 1995) would require 300 km of dextral movement.

The amount of displacement on the Odra Fault must have been very large if the basement block between the Odra and Dolsk Faults is a displaced fragment of the Rhenohercynian Zone. However, it is also possible that this part of the basement represents another section of the Laurussia margin affected by the Variscan tectono-metamorphic imprint. Such a possibility is reconcilable with the strike-slip model (Fig. 12a) but makes estimates of displacement along the Odra Fault uncertain.

\section{Semi-orolicline model}

Since the seismic refraction models (Grad et al. 2003, 2008) image the Variscan-type crust with a velocity structure fitting that of the orogenic basement between the Odra and Dolsk Faults (Wolsztyn Block; Fig. 11), this crustal block might have been affected by Variscan deformation and metamorphism. This is supported by the presence of phyllites with the latest Devonian-earliest Carboniferous low-grade metamorphic overprint in the basement of the Wolsztyn High (Mazur et al. 2006b). A comparable tectonic setting of a passive margin accreted to an orogenic wedge has been imaged by the DEKORP line crossing the Rhenohercynian Zone (e.g. Oncken et al. 1999). Following this analogy, a crustal block between the Odra and Dolsk Faults can represent an extension of the Northern Phyllite Zone (Franke et al. 2017), right-laterally displaced by WNW-ESE directed shearing (Fig. 12a).

An alternative solution is a 'semi-orocline' involving the Northern Phyllite and Rhenohercynian Zones, reoriented by a strike slip-related bending to assume the WNW-ESE trend (Fig. 12b; Franke and Żelaźniewicz 2002; Winchester et al. 2002; Franke et al. 2017). Geophysical data do not show regional bending of the structural grain in the Variscan foreland, but this may occur farther NW in eastern Germany, which is not covered by our data. In such a model, the Odra Fault would represent a cryptic Rhenohercynian Suture with the SSW tectonic polarity in the present-day coordinates (Fig. 12b).

Still another possibility would be an oroclinal loop developed between the Wolsztyn Block and the allochthonous units of the Moravo-Silesian Fold-and-Thrust Belt (MSB in Fig. 11). Such a link is partly suggested by the southward bending $\left(\mathrm{c} .40^{\circ}\right)$ of the Odra Fault east of Wrocław and the gravity anomalies associated (Figs. 5, 7). In this scenario, a low-grade to non-metamorphic rock series envelope the Staré Město (Moravian) Suture, which is terminated by the Odra Fault in the north. However, the latter suture cannot be equivalent to the Rhenohercynian one because of their mutually opposite polarity. Furthermore, the potential oroclinal loop is absent from the Variscan externide belt farther north.

\section{NE-SW shortening}

A peculiar feature of the band-pass filtered gravity anomaly pattern as well as other derivatives of gravity and magnetic fields is the lack of continuity between the Odra and Kraków-Lubliniec Faults (Figs. 5, 7). This is in-line with the results of along-strike comparison of cross-sections A and B (Fig. 8) that casts shadow on the continuity of these two faults based on geological premises. If this is a primary feature it would imply a limited amount of late Variscan 
displacement along the latter fault. However, the possible original continuity of the Odra and Kraków-Lubliniec Faults could have been disturbed by the younger Moravian Shear Zone (Rajlich 1990a, b) that is oriented approximately perpendicular to both the faults (Fig. 11). The clockwise bend of the Odra Fault and gravity anomalies north of it (Fig. 5, 7) may suggest an important right-lateral displacement event in the zone east of the Staré Město Suture.

The dextral sense of movement on the Moravian Shear Zone is consistent with the kinematics of other late Variscan deformations, post-dating the phase of dextral displacements along the WNW-ESE faults (Fig. 11) and with the NE-SW to NNE-SSW directed regional shortening that affected the entire Variscan foreland at that time. The stratigraphic information allows to constrain the timing of this late Variscan deformation event to the late Westphalian (c. 305-300 Ma; Mazur et al. 2010; Waksmundzka 2014).

The continuation of the Variscan deformation front at least to the Polish-Ukrainian border (Figs. 5, 7, 11) suggests that the late orogenic push toward the NE had its source in the southern area of the present-day Carpathians. Consequently, the Variscan shortening must have been transferred to the shallow margin of the EEC across the whole assemblage of pre-Variscan structural and paleogeographic units of SE Poland. We speculate that the Variscan orogenic belt was enveloping the Brunovistulian Terrane also from the south, being the main source of EEC-ward directed shortening. Paleotectonic maps in Matte $(1986,1991)$ indicate a continuation of the Variscan belt around the southern perimeter of Laurussia approximately to the present Caucasus area. Variscan basement closest to the external Variscide belt of SE Poland is exposed in the Tatra Mts. and contains relics of an oceanic crust of the Tornquist Ocean involved in Variscan nappe stacking and metamorphism (Gawęda et al. 2017). The Variscan complex of the Tatra Mts. belongs, however, to the far-travelled Adria-derived group of units (Schmid et al. 2008) and its original location with respect to Baltica and position within the Variscan orogen is uncertain. Nevertheless, despite the allochthonous character of the pre-Alpine Western Carpathians basement, Variscan and Cadomian age spectra were obtained from metamorphic and igneous clasts in debris flows in the external flysch nappes (Poprawa et al. 2005; Budzyń et al. 2011; Oszczypko et al. 2016). Palinspastic restorations place source areas $<100 \mathrm{~km}$ south of the of the European Plate margin (Roca et al. 1995; Nemčok et al. 2001) that evidences a persistence of exposed Neoproterozoic-Variscan basement in that area at least until the Palaeocene. This refers, however, to a post-rifting paleogeography, whereas a pre-Jurassic position of Variscan source areas for the Outer Carpathian debris flows must have been more proximal. Consequently, the Małopolska Block and Brunovistulian Terrane must have once bordered from the south on the Variscan orogen that induced N-S compression in its northern foreland.

\section{Discussion and conclusions}

The shape of the Variscan deformation front in the map view, together with the WNW-ESE orientation of the regional structural grain (Fig. 6), parallel to major strikeslip faults, are inconsistent with the presence of an oroclinal loop within the external, non-metamorphic Variscan belt. Our geophysical and geological data also favour a dextral strike-slip contact between the internal zones of the Variscan orogen (Bohemian Massif) and its northern foreland (Polish Lowland), on which the Variscan external fold-thrust belt has developed (Fig. 12a). However, a semi-oroclinal geometry i.e., a c. $90^{\circ}$ bend of the North Phyllite Zone, masked by younger sediments in NE Germany (Fig. 12b; e.g. Winchester et al. 2002; Franke and Żelaźniewicz 2000, 2002), is still possible. Such a pattern would imply a continuity of the Rhenohercynian Suture as a cryptic feature along the Odra Fault, with its ESE ending remaining enigmatic. The latter problem was addressed by Winchester et al. (2002), who proposed a concept of the so-called Moravian Line.

The Moravian Line is thought to represent the NNE-SSW oriented eastern plate boundary of East Avalonia that is currently aligned subparallel to, though genetically unrelated with the Staré Město (Moravian) Suture. In this concept, Winchester et al. (2002) refer to geophysical evidence provided by a crustal boundary imaged on the POLONAISE' 97 P1 seismic refraction profile (Jensen et al. 1999). Indeed, the P1 line crosscuts the Dolsk Fault (Fig. 2), imaging a boundary between the low-velocity Variscan-type crust in the SE part of the P1 profile and the three-layer crust of the Palaeozoic Platform in its NW part (Jensen et al. 1999, their Fig. 6). The highly oblique intersection of the Dolsk Fault with the P1 profile appears moderately inclined (Jensen et al. 1999). Consequently, Winchester et al. (2002) assumed that the boundary imaged by the P1 profile represented a feature roughly orthogonal to the section and, in this way, pinpointed location of the hypothetical N-S oriented Moravian Line. The latter is, however, not confirmed by either potential field data (this paper), seismic velocity models (Grad and Polkowski 2016) or borehole structural data (Mazur et al. 2010 and this paper) and, thus, most probably does not exist.

The problem of the SE termination of the Wolsztyn Block (Fig. 11), comprising low-grade Variscan basement, would be solved if the latter continues into the allochthonous units of the Moravo-Silesian fold-and-thrust belt, comprising Devonian-Tournaisian deep water basinal facies (e.g. Bábek et al. 2006). Such an oroclinal bend would be squeezed between the Varican internides in the south and Varican foreland rigid basement in the north and restricted 
to a narrow zone of low-grade to non-metamorphic preorogenic sediments.

The strike-slip kinematic model proposed in this paper can be well correlated with the sequence of tectonic events in the European Variscan belt during late Palaeozoic times that was proposed by Edel et al. (2018). According to these authors, the late Palaeozoic relocation of subduction to the northern margin of the Palaeotethys Ocean was responsible for $\mathrm{N}-\mathrm{S}$ shortening of the Variscan belt at around 335-325 Ma. This deformation resulted in dextral reactivation of transform boundaries associated with anticlockwise rotation of intermittent blocks as major strike-slip faults (Edel et al. 2018; their Fig. 7). These WNW-ESE trending faults remained active during the subsequent transtensional event at 325-310 Ma that is also consistent with our kinematic strike-slip model. During this latter event new sets of sinistral, NNE-SSW trending transfer faults also originated (Edel et al. 2018), one of them being the Moravian Shear Zone. The whole system subsequently suffered a period of NNE-SSW shortening at 310-300 Ma that affected the Variscan belt along the former Laurussian plate boundary due to a hard collision with Gondwana. This deformation event was associated with the clockwise rotation of Laurussia together with the accreted northern sector of the Variscan belt and the anticlockwise one of Gondwana (Edel et al. 2018) and corresponded to the final stage of the then orogenic shortening in Poland that created the Variscan deformation front (Fig. 11).

Acknowledgements S. Mazur and P. Krzywiec acknowledge financial support from the Polish National Science Centre grant no. UMO2017/25/B/ST10/01348. Gravity and magnetic data used in our study can be obtained from the National Geological Archive and Central Geological Database (CGDB) managed by the Polish Geological Institute. The authors thank Pavla Štípská for editorial handling of the paper. Constructive comments from the reviewers, Jean-Bernard Edel, and Wolfgang Franke, helped to improve our work.

Open Access This article is licensed under a Creative Commons Attribution 4.0 International License, which permits use, sharing, adaptation, distribution and reproduction in any medium or format, as long as you give appropriate credit to the original author(s) and the source, provide a link to the Creative Commons licence, and indicate if changes were made. The images or other third party material in this article are included in the article's Creative Commons licence, unless indicated otherwise in a credit line to the material. If material is not included in the article's Creative Commons licence and your intended use is not permitted by statutory regulation or exceeds the permitted use, you will need to obtain permission directly from the copyright holder. To view a copy of this licence, visit http://creativecommons.org/licenses/by/4.0/.

\section{References}

Aleksandrowski P (1990) Early Carboniferous strike-slip displacements at the northeastern periphery of the Variscan belt in Central
Europe. In: International Conference on Paleozoic orogens in Central Europe (Terranes in the Circum-Atlantic Paleozoic orogens, IGCP Program 233), Abstracts: 7-10, Göttingen

Aleksandrowski P (1995) The significance of major strike-slip displacements in the development of Variscan structure of the Sudetes (SW Poland). Przegląd Geologiczny 43:745-754 (in Polish, English abstract)

Aleksandrowski P, Mazur S (2002) Collage tectonics in the northeasternmost part of the Variscan Belt: the Sudetes, Bohemian Massif. In: Winchester JA, Pharaoh TC, Verniers J (eds) Palaeozoic Amalgamation of Central Europe, vol 201. Geological Society, Special Publications, London, pp 237-277. https://doi. org/10.1144/GSL.SP.2002.201.01.12

Aleksandrowski P, Kryza R, Mazur S, Żaba J (1997) Kinematic data on major Variscan strike-slip faults and shear zones in the Polish Sudetes, northeast Bohemian Massif. Geol Mag 133:727-739

Antonowicz L, Iwanowska E (2004) Thin-skinned tectonics of the Lublin Basin. Przegląd Geologiczny 52:128-130 (in Polish, English abstract)

Antonowicz L, Hooper R, Iwanowska E (2003) Lublin syncline as a result of thin-skinned Variscan deformation (SE Poland). Przegląd Geologiczny 51:344-350 (in Polish, English abstract)

Arthaud F, Matte P (1977) Late Paleozoic strike-slip faulting in southern Europe and northern Africa: result of a right-lateral shear zone between the Appalachians and the Urals. Geol Soc Am Bull 88(9):1305-1320. https://doi.org/10.1130/00167606(1977)88\%3c1305:LPSFIS\%3e2.0.CO;2

Bábek O, Tomek C, Melichar R, Kalvoda J, Otava J (2006) Structure of unmetamorphosed Variscan tectonic units of the southern Moravo-Silesian Massif: a review. Neues Jb Geol Paläontol Abh 239(1):37-75

Badham JPN (1982) Strike-slip orogens-an explanation for the Hercynides. J Geol Soc Lond 139:493-504. https://doi. org/10.1144/gsjgs.139.4.0493

Banka D, Pharaoh TC, Williamson JP, TESZ Project Potential Field Core Group (2002) Potential field imaging of Palaeozoic orogenic structure in northern and central Europe. Tectonophysics 360:23-45

Bartholomew MJ, Whitaker AE (2010) The Alleghanian deformational sequence at the foreland junction of the Central and Southern Appalachians. In: Tollo RP, Bartholomew MJ, Hibbard JP, Karabinos PM (eds) From Rodinia to Pangea: the lithotectonic record of the appalachian Region, vol 206. Geological Society of America Memoir, Mclean, pp 431-454. https ://doi.org/10.1130/2010.1206(19)

Bederke E (1930) Oberschlesien und das varistische Gebirge. Geol Rundsch 21:234-242

Behr HJ, Engel W, Franke W (1982) Variscan wildflysch and nappe tectonics in the Saxothuringian Zone (northeast Bavaria, West Germany). Am J Sci 282(9):1438-1470. https://doi. org/10.2475/ajs.282.9.1438

Behr HJ, Engel W, Franke W, Giese P, Weber K (1984) The Variscan belt in Central Europe: main structures, geodynamic implications, open questions. Tectonophysics 109(1-2):15-40. https ://doi.org/10.1016/0040-1951(84)90168-9

Berg G (1913) Beiträge zur Geologie von Niederschlesien mit besonderer Berücksichtigung der Erzlagerstätten in den Nordsudeten. Abhandlungen der Königlich Preußischen Geologischen Landesanstalt, Neue Folge 74:1-73

Bertrand R (1887) La chaîne des Alpes et la formation du continent Européen. Bulletin de la Société géologique de France, Série 3(15):423-447

Blakely RJ (1996) Potential theory in gravity and magnetic applications. Cambridge University Press, New York, p 441

Budzyń B, Dunkley DJ, Kusiak MA, Poprawa P, Malata T, Skiba M, Paszkowski M (2011) Shrimp U-Pb zircon chronology of 
the Polish Western Outer Carpathians source areas. Ann Soc Geol Pol 81:161-171

Buła Z (2000) The Lower Palaeozoic of Upper Silesia and West Małopolska. Prace Państwowego Instytytu Geologicznego 171:1-89

Buła Z, Habryn R (2011) Precambrian and Palaeozoic basement of the Carpathian Foredeep and the adjacent Outer Carpathians (SE Poland and western Ukraine). Ann Soc Geol Pol 81(3):221-239

Buła Z, Jachowicz M, Żaba J (1997) Principal charakteristics of the Upper Silesian Block and Małopolska Block border zone. Geol Mag 134(5):669-677

Buła Z, Habryn R, Jachowicz-Zdanowska M, Żaba J (2015) Precambrian and Lower Paleozoic of the Brunovistulicum (eastern part of the Upper Silesian Block, southern Poland) - the state of the art. Geol Q 59(1):123-134. https://doi.org/10.7306/gq.1203

Central Geological Database (2019) Polish Geological Institute. http:// baza.pgi.gov.pl/. Accessed 11 Jan 2019

Chopin F, Schulmann K, Skrzypek E, Lehmann J, Dujardin JR, Martelat JE, Lexa O, Corsini M, Edel JB, Štípská P, Pitra P (2012) Crustal influx, indentation, ductile thinning and gravity redistribution in a continental wedge: building a Moldanubian mantled gneiss dome with underthrust Saxothuringian material (European Variscan belt). Tectonics. https://doi.org/10.1029/2011TC002951

Dadlez R (2006) The Polish Basin-relationship between the crystalline, consolidated and sedimentary crust. Geol Q 50(1):43-58

Dadlez R, Kowalczewski Z, Znosko J (1994) Some key problems of the pre-Permian tectonics of Poland. Geol Q 38(2):169-189

Dadlez R, Narkiewicz M, Stephenson RA, Visser MTM, van Wees J-D (1995) Tectonic evolution of the Mid-Polish Trough: modelling implications and significance for central European geology. Tectonophysics 252(1-4):179-195

Dadlez R, Marek S, Pokorski J (2000) Geological map of Poland without Cenozoic deposits scale 1:1000000. Polish Geological Institute, Warszawa

Dewey JF, Burke KC (1973) Tibetan, Variscan, and Precambrian basement reactivation: products of continental collision. J Geol 81(6):683-692. https://doi.org/10.1086/627920

Don J (1990) The differences in Paleozoic facies-structural evolution of the West Sudetes. Neues Jb Geol Paläontol Abh $179(2 / 3): 307-328$

Dörr W, Żelaźniewicz A, Bylina P, Schastok J, Franke W, Haack U, Kulicki C (2006) Tournaisian age of granitoids from the Odra Fault Zone (southwestern Poland): equivalent of the MidGerman Crystalline High? Int J Earth Sci 95(2):341-349. https ://doi.org/10.1007/s00531-005-0044-8

Eckelmann K, Nesbor H-D, Königshof P, Linnemann U, Hofmann M, Lange J-M, Sagawe A (2014) Plate interactions of Laurussia and Gondwana during the formation of Pangaea-constraints from U-Pb LA-SF-ICP-MS detrital zircon ages of Devonian and early Carboniferous siliciclastics of the Rhenohercynian zone, Central European Variscides. Gondwana Res 25:14841500. https://doi.org/10.1016/j.gr.2013.05.018

Edel JB, Weber K (1995) Cadomian terranes, wrench faulting and thrusting in the central Europe Variscides: geophysical and geological evidence. Geol Rundsch 84(2):412-432. https://doi. org/10.1007/BF00260450

Edel JB, Schulmann K, Holub FV (2003) Anticlockwise and clockwise rotations of the Eastern Variscides accommodated by dextral lithospheric wrenching: palaeomagnetic and structural evidence. J Geol Soc 160(2):209-218. https://doi. org/10.1144/0016-764902-035

Edel JB, Schulmann K, Lexa O, Lardeaux JM (2018) Late Palaeozoic palaeomagnetic and tectonic constraints for amalgamation of Pangea supercontinent in the European Variscan belt.
Earth Sci Rev 177:589-612. https://doi.org/10.1016/j.earsc irev.2017.12.007

Ellenberger F, Tamain ALG (1980) Hercynian Europe. Episodes $1(1): 22-25$

Engel W, Franke W, Langenstrassen F (1983) Palaeozoic sedimentation in the northern branch of the mid-European Variscides-essay of an interpretation. In: Martin H, Eder FW (eds) Intracontinental fold belts. Springer, Berlin, pp 9-41

Fairhead JD (2016) Advances in gravity and magnetic processing and interpretation. EAGE, Houten, p 338

Franke W (1989a) Tectonostratigraphic units in the Variscan belt of central Europe. Geol Soc Am Spec Pap 230:67-90

Franke W (1989b) Variscan plate tectonics in Central Europe-current ideas and open questions. Tectonophysics 169:221-228. https://doi.org/10.1016/0040-1951(89)90088-7

Franke W (2000) The mid-European segment of the Variscides: tectonostratigraphic units, terrane boundaries and plate tectonic evolution. In: Franke W, Haak V, Oncken O, Tanner D (eds) Orogenic processes: quantification and modelling in the Variscan belt, vol 179. Geological Society, Special Publications, London, pp 35-61. https://doi.org/10.1144/GSL. SP.2000.179.01.05

Franke W (2014) Topography of the Variscan orogen in Europe: failed-not collapsed. Int J Earth Sci 103:1471-1499. https:// doi.org/10.1007/s00531-014-1014-9

Franke W, Żelaźniewicz A (2000) The eastern termination of the Variscides: terrane correlation and kinematic evolution. In: Franke W, Haak V, Oncken O, Tanner D (eds) Quantification and modelling in the Variscan Belt, vol 179. Geological Society, Special Publications, London, pp 63-86. https://doi.org/10.1144/GSL. SP.2000.179.01.06

Franke W, Żelaźniewicz A (2002) Structure and evolution of the Bohemian Arc. In: Winchester JA, Pharaoh TC, Verniers J (eds) Palaeozoic Amalgamation of Central Europe, vol 201. Geological Society, Special Publications, London, pp 279-293. https://doi. org/10.1144/GSL.SP.2002.201.01.13

Franke W, Żelaźniewicz A, Porębski SJ, Wajsprych B (1993) Saxothuringian zone in Germany and Poland: differences and common features. Geol Rundsch 82(3):583-599. https://doi.org/10.1007/ BF00212418

Franke W, Dallmeyer RD, Weber K (1995) Geodynamic evolution. In: Dallmeyer RD, Franke W, Matte P (eds) Pre-Permian geology of Central and Eastern Europe. Springer, Berlin, pp 579-593

Franke W, Cocks LRM, Torsvik TH (2017) The Palaeozoic Variscan oceans revisited. Gondwana Res 48:257-284. https://doi. org/10.1016/j.gr.2017.03.005

Gawęda A, Burda J, Golonka J, Klötzli U, Chew D, Szop K, Wiedenbeck M (2017) The evolution of Eastern Tornquist-Paleoasian Ocean and subsequent continental collisions: a case study from the Western Tatra Mountains, Central Western Carpathians (Poland). Gondwana Res 48:134-152. https://doi.org/10.1016/j. gr.2017.04.021

Geißler M, Breitkreuz C, Kiersnowski H (2008) Late Paleozoic volcanism in the central part of the Southern Permian Basin (NE Germany, W Poland): facies distribution and volcano-topographic hiati. Int J Earth Sci 97(5):973-989. https://doi.org/10.1007/ s00531-007-0288-6

Getech (2019) Getech Group plc. https://getech.com/software-devel opment/. Accessed 28 Jan 2019

Gotte W, Hirschmann G (1972) Geologische Übersichtskarte DDR 1:400,000, Bezirke Dresden, Karl_Marx-Stadt. Keipzig, Freiberg

Grabowski J, Bábek O, Nawrocki J, Tomek Č (2008) New palaeomagnetic data from the Palaeozoic carbonates of the Moravo-Silesian Zone (Czech Republic): evidence for a timing and origin of the late Variscan remagnetization. Geol Q 52(4):321-334 
Grad M, Polkowski M (2016) Seismic basement in Poland. Int J Earth Sci 105(4):1199-1214. https://doi.org/10.1007/s0053 1-015-1233-8

Grad M, Jensen SL, Keller GR, Guterch A, Thybo H, Janik T, Tiira T, Yliniemi J, Luosto U, Motuza G, Nasedkin V (2003) Crustal structure of the Trans-European suture zone region along POLONAISE'97 seismic profile P4. J Geophys Res Solid Earth. https ://doi.org/10.1029/2003JB002426

Grad M, Guterch A, Mazur S, Keller GR, Špičák A, Hrubcová P, Geissler WH (2008) Lithospheric structure of the Bohemian Massif and adjacent Variscan belt in central Europe based on profile S01 from the SUDETES 2003 experiment. J Geophys Res Solid Earth. https://doi.org/10.1029/2007JB005497

Guterch A, Grad M (2006) Lithospheric structure of the TESZ in Poland based on modern seismic experiments. Geol Q 50(1):23-32

Hatcher RD (2002) Alleghanian (Appalachian) orogeny, a product of zipper tectonics: Rotational transpressive continent-continent collision and closing of ancient oceans along irregular margins. In: Martinez Catalán JR, Hatcher RD Jr, Arenas R, Díaz Garcia $\mathrm{F}$ (eds) Variscan-Appalachian dynamics: the building of the late paleozoic basement, vol 364. Geological Society of America Special Paper, Mclean, pp 199-208

Janoušek V, Aichler J, Hanžl P, Gerdes A, Erban V, Žáček V, Pecina V, Pudilová M, Hrdličková K, Mixa P, Žáčková E (2014) Constraining genesis and geotectonic setting of metavolcanic complexes: a multidisciplinary study of the Devonian Vrbno Group (Hrubý Jeseník Mts., Czech Republic). Int J Earth Sci 103(2):455-483. https://doi.org/10.1007/s00531-013-0975-4

Jensen SL, Janik T, Thybo H, POLONAISE Profile P1 Working Group (1999) Seismic structure of the Palaeozoic Platform along POLONAISE'97 profile P1 in northwestern Poland. Tectonophysics 314(1-3):123-143. https://doi.org/10.1016/S0040 -1951(99)00240-1

Jeřábek P, Faryad WS, Schulmann K, Lexa O, Tajčmanova L (2008) Alpine burial and heterogeneous exhumation of Variscan crust in the West Carpathians: insight from thermodynamic and argon diffusion modelling. J Geol Soc 165(2):479-498. https://doi. org/10.1144/0016-76492006-165

Jeřábek P, Konopásek J, Žáčková E (2016) Two-stage exhumation of subducted Saxothuringian continental crust records underplating in the subduction channel and collisional forced folding (Krkonoše-Jizera Mts., Bohemian Massif). J Struct Geol 89:214-229. https://doi.org/10.1016/j.jsg.2016.06.008

Jubitz KB, Znosko J, Franke D (eds) (1986) Tectonic Map, International Geological Correlation Programme, Project No 86: SouthWest Border of the East European Platform. Zentralblatt für Geologie und Paläontologie, Geologische Institut, Berlin

Kiersnowski H, Peryt TM, Buniak A, Mikołajewski Z (2010) From the intra-desert ridges to the marine carbonate island chain: middle to late Permian (Upper Rotliegend-Lower Zechstein) of the Wolsztyn-Pogorzela high, west Poland. Geol J 45(2-3):319-335. https://doi.org/10.1002/gj.1189

Konon (2008) Tectonic subdivision of Poland: Holy Cross Mountains and adjacent areas. Przegląd Geologiczny 56:921-926 (in Polish, English abstract)

Konopásek J, Anczkiewicz R, Jeřábek P, Corfu F, Žáčková E (2019) Chronology of the Saxothuringian subduction in the West Sudetes (Bohemian Massif, Czech Republic and Poland). J Geol Soc Lond 176(3):492-504. https://doi.org/10.1144/jgs2018-173

Kossmat F (1927) Gliederung des varistischen Gebirgsbaues. Abhandlungen Sächsischen Geologischen Landesamts 1:1-39

Králiková S, Vojtko R, Hók J, Fügenschuh B, Kováč M (2016) Lowtemperature constraints on the Alpine thermal evolution of the Western Carpathian basement rock complexes. J Struct Geol 91:144-160. https://doi.org/10.1016/j.jsg.2016.09.006
Krs M, Pruner P (1995) Paleomagnetism and paleogeography of the Variscan Formations of the Bohemian Massif, comparison with other European regions. J Czech Geol Soc 40:3-46

Krs M, Hladil J, Krsova M, Pruner P (1995) Paleomagnetic evidence for Variscan paleotectonic rotation of Moravian Devonian rocks. Geologické výzkumy na Moravě a ve Slezsku v roce 1994:53-57 (in Czech, English abstract)

Krzywiec P, Malinowski M, Mazur S, Buffenmyer V, Lewandowski M (2014) Structure and Phanerozoic evolution of the SW edge of the East European Craton in Poland-new insight from higheffort seismic reflection data (project PolandSPAN). Geologia Sudetica 42:46-48

Krzywiec P, Mazur S, Gagała Ł, Kufrasa M, Lewandowski M, Malinowski M, Buffenmyer V (2017a) Late Carboniferous thinskinned compressional deformation above the SW edge of the East European craton as revealed by seismic reflection and potential field data-correlations with the Variscides and the Appalachians. In: Law RD, Thigpen JR, Merschat AJ, Stowell HH (eds) Linkages and feedbacks in orogenic systems, vol 213. Geological Society of America Memoir, Mclean, pp 353-372

Krzywiec P, Gagała $€$, Mazur S, Słonka $€$, Kufrasa M, Malinowski M, Pietsch K, Golonka J (2017b) Variscan deformation along the Teisseyre-Tornquist Zone in SE Poland: thick-skinned structural inheritance or thin-skinned thrusting? Tectonophysics 718:8391. https://doi.org/10.1016/j.tecto.2017.06.008

Krzywiec P, Poprawa P, Mikołajczak M, Mazur S, Malinowski M (2018) Deeply concealed half-graben at the SW margin of the East European Craton (SE Poland) —evidence for Neoproterozoic rifting prior to the break-up of Rodinia. J Palaeogeogr 7:88-97. https://doi.org/10.1016/j.jop.2017.11.003

Książkiewicz M, Samsonowicz J, Rühle E (1965) Outline Geology of Poland. Warszawa, Wydawnictwa Geologiczne, p 380 (in Polish)

Kufrasa M, Stypa A, Krzywiec P, Słonka $€$ (2019) Late Carboniferous thin-skinned deformation in the Lublin Basin, SE Poland: results of combined seismic data interpretation, structural restoration, and subsidence analysis. Annales Societatis Geologorum Poloniae 89:175-194. https://doi.org/10.14241/asgp.2019.09

Lewandowski M (2003) Assembly of Pangea: combined paleomagnetic and paleoclimatic approach. Adv Geophys 46:199-236. https://doi.org/10.1016/S0065-2687(03)46003-2

Lexa O, Schulmann K, Janoušek V, Štípská P, Guy A, Racek M (2011) Heat sources and trigger mechanisms of exhumation of HP granulites in Variscan orogenic root. J Metamorph Geol 29:79-102. https://doi.org/10.1111/j.1525-1314.2010.00906.x

Lorenz V (1976) Formation of Hercynian subplates; possible causes and consequences. Nature 262:374-377. https://doi org/10.1038/262374a0

Lorenz V, Nicholls IA (1984) Plate and intraplate processes of Hercynian Europe during the late Paleozoic. Tectonophysics 107(1-2):25-56. https://doi.org/10.1016/0040-1951(84)90027 $-1$

MacLeod IN, Jones K, Dai TF (1993) 3-D analytic signal in the interpretation of total magnetic field data at low magnetic latitudes. Explor Geophys 24:679-691. https://doi.org/10.1071/EG993 $679 \mathrm{u} 2$

Majdański M (2012) The structure of the crust in TESZ area by kriging interpolation. Acta Geophys 60:59-75. https://doi.org/10.2478/ s11600-011-0058-5

Malinowski M, Żelaźniewicz A, Grad M, Guterch A, Janik T, CELEBRATION Working Group (2005) Seismic and geological structure of the crust in the transition from Baltica to Palaeozoic Europe in SE Poland-CELEBRATION 2000 experiment, profile CEL02. Tectonophysics 401(1-2):55-77. https://doi. org/10.1016/j.tecto.2005.03.011

Malinowski M, Grad M, Guterch A, Takács E, Śliwiński Z, Antonowicz L, Iwanowska E, Keller GR, Hegedűs E (2007) Effective 
sub-Zechstein salt imaging using low-frequency seismicsresults of the GRUNDY 2003 experiment across the Variscan front in the Polish Basin. Tectonophysics 439:89-106. https:// doi.org/10.1016/j.tecto.2007.03.006

Malinowski M, Guterch A, Narkiewicz M, Probulski J, Maksym A, Majdański M, Środa P, Czuba W, Gaczyński E, Grad M, Janik T, Jankowski L, Adamczyk A (2013) Deep seismic reflection profile in Central Europe reveals complex pattern of Paleozoic and Alpine accretion at the East European Craton margin. Geophys Res Lett 40(15):3841-3846. https://doi.org/10.1002/grl.50746

Martínez Catalán JR (2011) Are the oroclines of the Variscan belt related to late Variscan strike-slip tectonics? Terra Nova 23:241247. https://doi.org/10.1111/j.1365-3121.2011.01005.x

Martínez Catalán JR, Collett S, Schulmann K, Aleksandrowski P, Mazur S (2020) Correlation of allochthonous terranes and major tectonostratigraphic domains between NW Iberia and the Bohemian Massif, European Variscan belt. Int J Earth Sci. https://doi. org/10.1007/s00531-019-01800-z

Matte P (1986) Tectonics and plate tectonics model for the Variscan belt of Europe. Tectonophysics 126:329-374. https://doi. org/10.1016/0040-1951(86)90237-4

Matte P (1991) Accretionary history and crustal evolution of the Variscan belt in Western Europe. Tectonophysics 196(3-4):309-337. https://doi.org/10.1016/0040-1951(91)90328-P

Matte P, Maluski H, Rajlich P, Franke W (1990) Terrane boundaries in the Bohemian Massif: result of large-scale Variscan shearing. Tectonophysics 177(1-3):151-170. https://doi. org/10.1016/0040-1951(90)90279-H

Mattern F (1996) The Elbe zone at Dresden-a Late Paleozoic pullapart intruded shear zone. Zeitschrift der Deutschen Geologischen Gesellschaft 147(1):57-80

Mazur S, Aleksandrowski P (2001) The Tepla (?)/Saxothuringian suture in the Karkonosze-Izera Massif, western Sudetes, Central European Variscides. Int J Earth Sci 90(2):341-360. https://doi. org/10.1007/s005310000146

Mazur S, Turniak K, Bröcker M (2004) Neoproterozoic and CambroOrdovician magmatism in the Variscan Kłodzko metamorphic complex (West Sudetes, Poland): new insights from $\mathrm{U} / \mathrm{Pb}$ zircon dating. Int J Earth Sci 93(5):758-772. https://doi.org/10.1007/ s00531-004-0417-4

Mazur S, Aleksandrowski P, Kryza R, Oberc-Dziedzic T (2006a) The Variscan Orogen in Po land. Geol Q 50(1):89-118

Mazur S, Dunlap WJ, Turniak K, Oberc-Dziedzic T (2006b) Age constraints for the thermal evolution and erosional history of the central European Variscan belt: new data from the sediments and basement of the Carboniferous foreland basin in western Poland. J Geol Soc 163(6):1011-1024. https://doi.org/10.1144/001676492004-170

Mazur S, Aleksandrowski P, Turniak K, Krzemiński L, Mastalerz K, Górecka-Nowak A, Kurowski L, Krzywiec P, Żelaźniewicz A, Fanning MC (2010) Uplift and late orogenic deformation of the Central European Variscan belt as revealed by sediment provenance and structural record in the Carboniferous foreland basin of western Poland. Int J Earth Sci 99(1):47-64. https://doi. org/10.1007/s00531-008-0367-3

Mazur S, Szczepański J, Turniak K, McNaughton NJ (2012) Location of the Rheic suture in the eastern Bohemian Massif: evidence from detrital zircon data. Terra Nova 24(3):199-206. https://doi. org/10.1111/j.1365-3121.2011.01053.x

Mazur S, Turniak K, Szczepański J, McNaughton NJ (2015a) Vestiges of Saxothuringian crust in the Central Sudetes, Bohemian Massif: zircon evidence of a recycled subducted slab provenance. Gondwana Res 27(2):825-839. https://doi.org/10.1016/j. gr.2013.11.005

Mazur S, Mikołajczak M, Krzywiec P, Malinowski M, Buffenmyer V, Lewandowski M (2015b) Is the Teisseyre-Tornquist Zone an ancient plate boundary of Baltica? Tectonics 34(12):2465-2477. https://doi.org/10.1002/2015TC003934

Mazur S, Gągała Ł, Kufrasa M, Krzywiec P (2018) Application of two-dimensional gravity models as input parameters to balanced cross-sections across the margin of the East European Craton in SE Poland. J Struct Geol 116:223-233. https://doi.org/10.1016/j jsg.2018.05.013

Mikołajczak M, Mazur S, Gąała $€$ (2019) Depth-to-basement for the East European Craton and Teisseyre-Tornquist Zone in Poland based on potential field data. Int J Earth Sci 108(2):547-567. https://doi.org/10.1007/s00531-018-1668-9

Nabighian M, Ander M, Grauch V, Hansen R, LaFehr T, Li Y, Pearson W, Peirce J, Phillips J, Ruder M (2005) Historical development of the gravity method in exploration. Geophysics 70(6):63ND89ND. https://doi.org/10.1190/1.2133785

Narkiewicz M (2007) Development and inversion of Devonian and Carboniferous basins in the eastern part of the Variscan foreland (Poland). Geol Q 51(3):231-256

Nawrocki J, Krzemiński L, Pańczyk M (2010) 40Ar-39Ar ages of selected rocks and minerals from the Kraków-Lubliniec Fault Zone, and their relation to the Paleozoic structural evolution of the Małopolska and Brunovistulian terranes (S Poland). Geol Q 54:289-300

Nemčok M, Nemčok J, Wojtaszek M, Ludhova L, Oszczypko N, Sercombe WJ, Cieszkowski M, Paul Z, Coward MP, Ślączka A (2001) Reconstruction of Cretaceous rifts incorporated in the Outer West Carpathian wedge by balancing. Mar Pet Geol 18:3964. https://doi.org/10.1016/S0264-8172(00)00045-3

Nowak J (1927) Zarys tektoniki Polski. II Zjazd Słowiańskich Geografów i Etnografów w Polsce, Kraków, pp 1-160 (in Polish)

Oberc J (1964) Main Sudetic diagonal fault and its significance for the position of the Variscan-laramide synclinoria. Kwartalnik Geologiczny 8(3):378-490 (In Polish; English summary)

Oberc J (1991) Systems of main longitudinal strike-slip faults in the vicinity of the Góry Sowie Block (Sudetes). Kwartalnik Geologiczny 35:403-420

Oberc-Dziedzic T, Żelaźniewicz A, Cwojdziński S (1999) Granitoids of the Odra Fault Zone: late-to post-orogenic Variscan intrusions in the Saxothuringian Zone, SW Poland. Geologia Sudetica 32:55-71

Oncken O, von Winterfeld C, Dittmar U (1999) Accretion of a rifted passive margin: the late Paleozoic Rhenohercynian fold and thrust belt (Middle European Variscides). Tectonics 18:75-91. https://doi.org/10.1029/98TC02763

Oszczypko N, Salata D, Konečný P (2016) Age and provenance of mica-schist pebbles from the Eocene conglomerates of the Tylicz and Krynica Zone (Magura Nappe, Outer Flysch Carpathians). Geol Carpath 67:257-271. https://doi.org/10.1515/geoca $-2016-0017$

Pharaoh TC (1999) Palaeozoic terranes and their lithospheric boundaries within the Trans-European Suture Zone (TESZ): a review. Tectonophysics 314(1-3):17-41

Poprawa P, Kusiak MA, Malata T, Paszkowski M, Pécskay Z, Skulich J (2005) Th-U-Pb chemical dating of monazite and K/Ar dating of mica combined: preliminary study of "exotic" crystalline clasts from the West ern Outer Carpathian flysch (Poland). Mineral Spec Pap 25:345-351

Pożaryski W, Dembowski Z (1983) Geological map of Poland and neighbouring countries without Cenozoic, Mesozoic and Permian deposits, scale 1:1000 000. Instytut Geologiczny, Warszawa

Pożaryski W, Karnkowski P (1992) Tectonic map of Poland during the Variscan time, 1:1000 000. Wydawnictwa Geologiczne, Warszawa 
Pożaryski W, Grocholski A, Tomczyk H, Karnkowski P, Moryc W (1992) The tectonic map of Poland in the Variscan epoch. Przegląd Geologiczny 40(11):643-651

Rajlich P (1987) Variszische duktile Tektonik im Bohmischen Massiv. Geol Rundsch 76:755-786. https://doi.org/10.1007/BF01821062

Rajlich P (1990a) Variscan shearing tectonics in the Bohemian Massif. Mineralogia Slovaca 22(1):33-40

Rajlich P (1990b) Strain and tectonic styles related to Variscan transpression and transtension in the Moravo-Silesian Culmian basin, Bohemian Massif. Czechoslovakia. Tectonophysics 174(3-4):351-367. https://doi.org/10.1016/0040-1951(90)90331 $-2$

Roca E, Bessereau G, Jawor E, Kotarba M, Roure F (1995) Pre-Neogene evolution of the Western Carpathians: constraints from the Bochnia-Tatra Mountains section (Polish Western Carpathians). Tectonics 14:855-873. https://doi.org/10.1029/95TC00828

Royden LH (1993) Evolution of retreating subduction boundaries formed during continental collision. Tectonics 12(3):629-638. https://doi.org/10.1029/92TC02641

Schmid SM, Bernoulli D, Fügenschuh B, Matenco L, Schefer S, Schuster R, Tischler M, Ustaszewski K (2008) The Alpine-CarpathianDinaridic orogenic system: correlation and evolution of tectonic units. Swiss J Geosci 101:139-183. https://doi.org/10.1007/ s00015-008-1247-3

Schulmann K, Konopásek J, Janoušek V, Lexa O, Lardeaux JM, Edel JB, Štípská P, Ulrich S (2009) An Andean type Palaeozoic convergence in the Bohemian massif. CR Geosci 341(2-3):266-286. https://doi.org/10.1016/j.crte.2008.12.006

Scrocca D, Carminati E, Doglioni C, Marcantoni D (2007) Slab retreat and active shortening along the central-northern Apennines. In: Lacombe O, Lavé J, Roure FM, Verges J (eds) Thrust belts and foreland basins: from fold kinematics to hydrocarbon systems. Frontiers in Earth Sciences, Springer, Berlin, Heidelberg, pp 471-487. https://doi.org/10.1007/978-3-540-69426-7

Seston R, Winchester JA, Piasecki MA, Crowley QG, Floyd PA (2000) A structural model for the western-central Sudetes: a deformed stack of Variscan thrust sheets. J Geol Soc Lond 157(6):11551167. https://doi.org/10.1144/jgs.157.6.1155

Simpson RW, Jachens RC, Blakely RJ, Saltus RW (1986) A new isostatic residual gravity map of the conterminous United States with a discussion on the significance of isostatic residual anomalies. J Geophys Res Solid Earth 91(B8):8348-8372. https://doi. org/10.1029/JB091iB08p08348

Słaby E, Breitkreuz C, Żaba J, Domańska-Siuda J, Gaidzik K, Falenty K, Falenty A (2010) Magma generation in an alternating transtensional-transpressional regime, the Kraków-Lubliniec Fault Zone, Poland. Lithos 119:251-268. https://doi.org/10.1016/j. lithos.2010.07.003

Spector A, Grant FS (1970) Statistical models for interpreting magnetic data. Geophysics 35(2):293-302. https://doi.org/10.1190/1.14400 92

Środa P, Czuba W, Grad M, Guterch A, Tokarski AK, Janik T, Rauch M, Keller GR, Hegedûs E, Vozár J, CELEBRATION 2000 Working Group (2006) Crustal and upper mantle structure of the Western Carpathians from CELEBRATION 2000 profiles CEL01 and CEL04: seismic models and geological implications. Geophys J Int 167:737-760. https://doi.org/10.1111/j.1365246X.2006.03104.x
Suess FE (1926) Intrusionstektonik und Wandertektonik im variszischen Grundgebirge. Gebrüder Borntraeger, Berlin, pp 1-268

Syberg FJR (1972) A Fourier method for the regional-residual problem of potential fields. Geophys Prospect 20(1):47-75. https://doi. org/10.1111/j.1365-2478.1972.tb00619.x

Tait JA, Bachtadse V, Soffel H (1996) Eastern Variscan fold belt: paleomagnetic evidence for oroclinal bending. Geology 24(10):871874. https://doi.org/10.1130/0091-7613(1996)024\%3c087 1:EVFBPE\%3e2.3.CO;2

Tait JA, Bachtadse V, Franke W, Soffel HC (1997) Geodynamic evolution of the European Variscan fold belt: palaeomagnetic and geological constraints. Geol Rundsch 86(3):585-598. https://doi. org/10.1007/s005310050165

Tomaszczyk M, Jarosiński M (2017) The Kock Fault Zone as an indicator of tectonic stress regime changes at the margin of the East European Craton (Poland). Geol Q 61(4):908-925. https://doi. org/10.7306/gq.1380

Waksmundzka MI (2014) Carboniferous coarsening-upward and nongradational cyclothems in the Lublin Basin (SE Poland): palaeoclimatic implications. In: Gąsiewicz A, Słowakiewicz M (eds) Palaeozoic climate cycles: their evolutionary and sedimentological impact, vol 376. Geological Society, Special Publications, London, pp 141-175. https://doi.org/10.1144/SP376.18

Weber K (1986) The Mid-European Variscides in terms of allochthonous terrains. In: Freeman R, Mueller S, Giese P (eds) Proc 3rd Worksh EGT: the central segment. 14. -16.4 1986, Eur Sci Found, Strasbourg, pp 73-82

Winchester JA, The PACE TMR Network Team (2002) Palaeozoic amalgamation of Central Europe: new results from recent geological and geophysical investigations. Tectonophysics 360(14):5-21. https://doi.org/10.1016/S0040-1951(02)00344-X

Żaba J (1999) The structural evolution of the Lower Paleozoic succession in the Upper Silesian Block and Małopolska Block border zone (Southern Poland). Prace Państwowego Instytutu Geologicznego 166:1-166

Žák J, Verner K, Janoušek V, Holub FV, Kachlík V, Finger F, Hajná J, Tomek F, Vondrovic L, Trubač J (2014) A plate-kinematic model for the assembly of the Bohemian Massif constrained by structural relationships around granitoid plutons. In: Schulmann K, Oggiano G, Lardeaux JM, Janoušek V, Martínez Catalán JR (eds) The Variscan orogeny: extent, timescale and the formation of the European crust, vol 405. Geological Society, Special Publications, London, pp 169-196. https://doi.org/10.1144/SP405.9

Żelaźniewicz A, Pańczyk M, Nawrocki J, Fanning M (2008) A Carboniferous/Permian, calc-alkaline, I-type granodiorite from the Małopolska Block, Southern Poland: implications from geochemical and U-Pb zircon age data. Geol Q 52:301-308

Żelaźniewicz A, Buła Z, Fanning M, Seghedi A, Żaba J (2009) More evidence on Neoproterozoic terranes in Southern Poland and southeastern Romania. Geol Q 53:93-124

Ziegler PA (1989) Evolution of Laurussia—a study in Late Palaeozoic plate tectonics. Kluwer Academic, Dordrecht, pp 1-115

Ziegler PA (1990) Geological Atlas of Western and Central Europe, 2nd edn. Shell Internationale Petroleum Maatschappij B.V, The Hague, pp 1-130 